\title{
GEOTOURISM as a Tool for Learning: A Geoitinerary in the Cilento, Vallo di Diano and Alburni Geopark (Southern Italy)
}

\author{
Nicoletta Santangelo ${ }^{1}$, , Vincenzo Amato ${ }^{2,3}$, Alessandra Ascione ${ }^{1}\left(\right.$, Elda Russo Ermolli ${ }^{1}(\mathbb{D}$ \\ and Ettore Valente ${ }^{1, *(D)}$ \\ 1 Department of Earth, Environmental and Resources Sciences, University of Naples Federico II, via Cinthia 21, \\ 80126 Naples, Italy; nicsanta@unina.it (N.S.); alessandra.ascione@unina.it (A.A.); ermolli@unina.it (E.R.E.) \\ 2 Department of Bioscience and Territory, University of Molise, C.da F. Lappone, 86090 Pesche (IS), Italy; \\ vamato@unisa.it \\ 3 Department of Science of the Cultural Heritage, University of Salerno, Campus of Fisciano, Via Giovanni \\ Paolo II, 132-84084 Fisciano (SA), Italy \\ * Correspondence: ettore.valente@unina.it
}

Received: 13 May 2020; Accepted: 2 June 2020; Published: 4 June 2020

\begin{abstract}
Geotourism" is a particular type of "sustainable tourism" that is still in an embryonic stage, especially in Italy. The main goal is the transmission of geological knowledge to increase the awareness about geoheritage, geo-resources and geo-hazards. The geoparks represent ideal sites, with a strong educational significance for students, teachers, geo-tourists, and guides interested in geological and environmental sciences, though at different levels. With this in mind, we propose a geoitinerary through some of the most geologically interesting coastal areas in the Cilento, Vallo di Diano, and Alburni Geopark. The aim of the geoitinerary is to provide a good example of how geosites could be promoted through geotourism and used as means of divulgation of geological and environmental knowledge. The selected sites are the San Marco coast, the Licosa Cape and the Elea-Velia archaeological area. They are included in the official list of geosites and geomorphosites of the Geopark and have a relevant stratigraphic and geoarcheological value. The San Marco coast and the Licosa Cape are the "best sites" in the Geopark where Quaternary coastal deposits and morphologies are represented. The Elea-Velia site is one of the most famous archeological sites in the Geopark, which is also representative of complex human-environment interactions. Despite their high scientific significance, the sites that we have selected are not included in a specific promoting program. We have so tried to fill this gap by providing the scientific background for their geotouristic promotion that could also serve as an instrument for the increase of the local economy.
\end{abstract}

Keywords: geoparks; geosites; geotourism; geological knowledge; geoarcheology

\section{Introduction}

The Cilento and Vallo di Diano National Park was founded in 1991 under the law 394/91 and it was included in the United Nations Educational, Scientific and Cultural Organization (UNESCO) World Heritage list in 1998. It gained the title of Geopark in 2010 and became a UNESCO Global Geopark in 2015. Global Geoparks have been defined as "Single, unified geographical areas where sites and landscapes of international geological significance are managed with a holistic concept of protection, education and sustainable development" [1,2]. Several authors [3-6] suggested, among the main purposes of a geopark, the preservation of geodiversity by means of geoeducation and geotourism. Geological education, that is, how geoscience, particularly the geological processes, and society are linked, is a basic resource for the social and economic development of any community because it 
increases the sensitivity and awareness of citizens in the respect of the environmental estate and natural disasters. Unfortunately, geological education is still a missing topic [7] as, for instance, in the context of global change and overexploitation of resources [8]. Reference [9] suggests that, by using geological themes significant to the public through interpretive media and educational packages, it is possible to create a "dialogue between the public and Earth's history", leading people towards an understanding of the important processes that control our planet. In this meaning, Geoparks and Geoturism may be very useful. According to several authors ([10-12] and references therein) "Geotourism" is an emerging type of sustainable tourism, which focuses on geosites and furnishes visitor knowledge, environmental education, and also amusement.

In this paper, we propose a geoitinerary along the Cilento, Vallo di Diano and Alburni Geopark coastal area, with the aim to provide a good example of how some geosites and geomorphosites could be promoted through geotourism and used as means of geological and environmental knowledge divulgation. Geologists always use field activity as a tool to teach their students; our goal is to demonstrate that the experience of coming directly in touch with a geological subject may be the most effective approach also for non-expert people. The coastal area of the Cilento Vallo di Diano and Alburni Geopark includes several geomorphosites, which represent good examples of both coastal features and evidence of past sea level fluctuations that occurred in response to global climate change. Several papers have already stressed the importance of increased awareness about climate change in coastal environments, also suggesting geotourism as a key action to reach this goal [13-17]. Coastal zones are typical examples of dynamic and sensitive environments, which evolve through different phenomena that act at different temporal and spatial scales [18]. They represent the interface where the land meets the sea and include river deltas, coastal plains, wetlands, beaches and dunes, reefs, lagoons, cliffs and other coastal features. All these areas are very sensitive to changes in response to sea-level rise or extreme weather events, which may cause or accelerate coastal erosion and retreat [19-21]. Approximately $60 \%$ of the world's population lives along coastal zones [22,23], which often represent a major environmental and economic resource, though under risk in the light of the present climatic trend [23] that is enhancing the naturally induced sea level rise. We planned a geoitinerary focused on the geological and geomorphological evidence (namely, sediments and landforms) of both the active dynamics and past sea level fluctuations along various coastal environments of the Cilento, Vallo di Diano and Alburni Geopark. Our aim was to give an example of how geomorphosites may be useful for educational purposes and providing teachers and touristic guides with didactic/explanatory material.

We selected some sites among those listed in the Geopark's geosites and geomorphosites inventory, choosing the ones with the following requirements: representativeness, availability, and potential educational approach. For each site, we chose one or more geological and geomorphological topics that are represented at the "best" and explained them in the simplest way, with the aim to transfer their scientific significance to an audience as wide as possible. To reach our educational goal, we followed the suggestions of Macadam [24], i.e.,: (i) choosing the message we want the tourists bring home, (ii) avoiding geological jargon, (iii) using more pictures and figures than words. In particular, we focused on the following messages:

(i) We want to make the tourists aware that natural environments are not static in space and time, but they may evolve and thus interact with human activities. The selected sites are excellent places to spread this message that could have a strong influence on people worldwide because coastal hazard phenomena are spread all over the world.

(ii) We want the tourists to become aware that the climate on Earth changed periodically, causing sea level fluctuations and, consequently, significant modifications to coastal environments. Understanding past climate changes and their effects on the environment may help to understand the present and future climate changes. It should be the occasion to reflect on natural induced climate changes and to become aware that in the postglacial period we are now living in, the human-induced climate changes are contributing to quicken the natural ones. 


\section{Study Area}

\subsection{Geological Setting}

The Cilento, Vallo di Diano, and Alburni Geopark is bounded by the Sele River plain to the north, the Vallo di Diano and the Tanagro River valley to the north-east, the Gulf of Policastro to the south, and the Tyrrhenian Sea to the west (Figure 1). The Cilento region is part of the Southern Apennines, a NE-directed fold and thrust belt developed in Neogene to Quaternary times [25-27]. At the surface, the mountain belt consists of both open marine Mesozoic stratigraphic units and continental margin successions composed of platform carbonates and pelagic deposits, covered by Neogene and late Miocene wedge-top basin clastics [28-30]. Due to the heterogeneous nature of outcropping rocks and its rugged topography, the Geopark is characterized by a very high degree of geodiversity [31,32]. Carbonate massifs with summit karst landscapes, bounded by steep structural slopes, are typical of the inner area of the park (Figure 1). In such ridges, karst cave systems associated with the most important underground water reservoirs of the region are preserved [33-35]. The carbonate massifs alternate with a hilly landscape, with gentle slopes and dendritic drainage pattern, where pelagic and clastic successions dominate [36-40]. They are represented by the Cilento Group deposits (age between 17.7 and 10.8 million years), with the Pollica and S. Mauro Formations, mainly made up of alternating sandstones, marls and puddingstones [41-43]. The basinal successions (age between 65 and 22 million years) are well exposed in the southern part of the study area (Ascea-Velia) and are made up of the Crete Nere formation, dark clayey successions more than $500 \mathrm{~m}$ thick [36,44]. All these units have been involved in the complex tectonic history leading to the formation of the Southern Apennine chain, and for this reason they appear strongly deformed by fault and fold systems [37,45]. During Quaternary times (last 2.6 million years), the study area emerged from the sea, and its landscape was shaped by the actions of different geomorphic processes (fluvial, coastal, aeolian) under the control of strong climate variations. Continental and marine Quaternary succession, mainly made up by conglomerates and sandstones, accumulated along the valleys of the main rivers (Alento, Mingardo and Bussento rivers) and along the coast in the areas of Santa Maria di Castellabate and San Marco di Castellabate (hereinafter and in the map of Figure 1 labelled Santa Maria and San Marco, respectively), Palinuro and Marina di Camerota [46-54]. Different kinds of geosites (structural, stratigraphic, paleontological, geomorphological) $[55,56]$ are witnesses of this significant geological heritage and have been listed in the geosites inventory of the Geopark [57]. The latter includes 160 geosites, 36\% of which with main stratigraphical, paleontological, and geological value, and $54 \%$ of which are considered as geomorphosites. Nevertheless, at $\sim 30$ years from the National Park foundation and 10 years from the Geopark recognition, the actions aiming at the promotion and divulgation of the geological estate of the area are still very few $[34,35,40,58-63]$. 


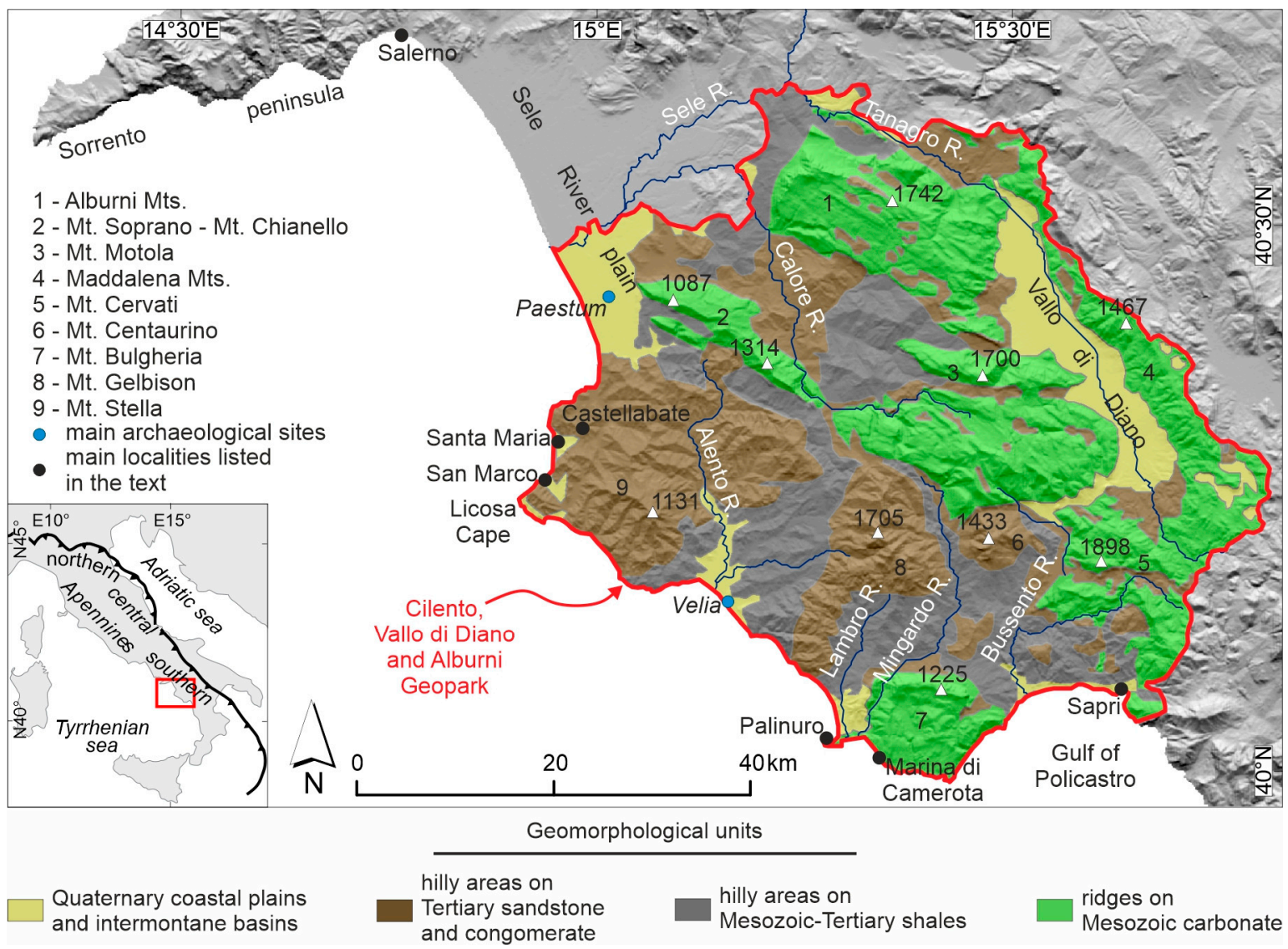

Figure 1. Location of the Cilento, Vallo di Diano, and Alburni Geopark, with indication of the geomorphological units and locations of the main archeological sites.

\subsection{Tourism in the Cilento, Vallo di Diano and Alburni Geopark}

It is important to bear in mind that Geotourism needs tourists. Unfortunately, the number of tourists that every year visit the Geopark is not monitored by both the Geopark management and the local administrations, e.g., municipalities, Provincia di Salerno and Regione Campania. Such a condition hampers the reconstruction of the tourist flux and its yearly/decadal variations, as already noted by other authors [64]. On the other hand, some information on the number of tourists visiting and spending nights in specific municipalities of the Geopark may be extracted from reports and analyses of the Italian Institute of Statistics (www.istat.it) and the Ente Provinciale del Turismo of Salerno [65]. These data indicate that more than two and up to four million people have visited the Geopark in the last four to five years. Information useful to outline the impact of the tourist traffic in the Geopark area is available from the Italian Ministry of Environment (https://www.minambiente.it/, [66]). Such information indicates that in the Geopark area there are 2931 active tourism companies, with 53,765 beds and 8762 people working in tourism-related economic activities. Within the entire Geopark, the coastal belt gets the largest number of both accommodation services and people working in touristic facilities and attractions [65]. Tourism in the Geopark is mainly concentrated in the summertime, with the beaches and coastal areas representing the main touristic attraction. For instance, the coastal areas caught more than $95 \%$ of the more than 2.4 million tourists that visited the Geopark in 2017 [66,67]. Worthy to note, among the Italian National Parks, the Cilento, Vallo di Diano and Alburni Geopark gains large visibility on the internet [65] even if an effective communication system through the web has not been developed so far by the Geopark administration. 


\section{Materials and Methods}

For the selection of sites, we followed the suggestions of Brilha [68], who states that sites with high potential educational value (EV) are those that have geological features that can be easily understood by students of different levels of education, with comfortable and quick access and where students may observe the site under good safety conditions. Similarly, sites with potential tourism value (TV) are those presenting visual beauty enjoyable by the majority of the public, with geological features that can be easily observed and understood by non-specialists, under good safety conditions, and with comfortable and quick access. Therefore, we have followed the Brilha [68] method to assess both the educational (Table 1) and the touristic (Table 2) values of coastal geosites in the Cilento, Vallo di Diano and Alburni Geopark. Moreover, to select the geosites that could be included in the geoitinerary, we analyzed the official list of the geosites of the Geopark reported in Aloia et al. [61] and we selected all the geosites placed along the coastal area that could be considered representative of sea level variations. According to Brilha [68], the educational value of a geosite derives from the sum of the relative scores of twelve indicators and their weights, which are the vulnerability (V), accessibility $(\mathrm{AC})$, use limitations (UL), safety (SA), logistics (L), density of population (DE), association with other values (AS), scenery (SC), uniqueness (UN), observation conditions (OC), didactic potential (DP) and geological diversity (GD). Similarly, the touristic value of a geosite derives from the same indicators of the educational value and their relative weights, with the exception of DP and GD that are replaced by the interpretative potential (IP), economic level (EL), and proximity of recreational areas (RA). Using the criteria listed above, we selected three geosites that gained the highest score of both indexes (Section 4), which are the San Marco site, the marine terrace of Punta Licosa, and the Elea-Velia site. In particular, the San Marco site can be considered as the best outcrop of Quaternary coastal deposits with well-preserved sedimentary structures along the entire coast of the Geopark, notwithstanding the presence of other important coastal sites and outcrops [46,51,52,54]. Moreover, the San Marco site is also explicative for the dynamics of rocky coasts and in particular for the formation and evolution of the sea cliffs. The Licosa cape is the best example of a marine terrace in the area of the Geopark. The Licosa cape marine terrace covers an area of more than $4 \mathrm{~km}$ in length and up to $500 \mathrm{~m}$ in width and has been the object of several scientific publications $[47,49,69]$. The Elea-Velia site is the second most important archaeological site in the Geopark, being only preceded by Paestum (Figure 1). Besides its archaeological value, it is also exemplary for the human/environment interaction in a flat coastal area characterised by coastline shifting [47,70-72]. 
Table 1. List of selected coastal geosites and indicators used to assess their educational value. The geosite number is from Aloia et al. [61]. The number below each indicator represents its relative weight.

\begin{tabular}{|c|c|c|c|c|c|c|c|c|c|c|c|c|c|}
\hline \multicolumn{14}{|c|}{ Educational Use of the Geosites } \\
\hline Indicator & $\begin{array}{l}\mathrm{V} \\
(10)\end{array}$ & $\begin{array}{l}\mathrm{AC} \\
(10)\end{array}$ & $\begin{array}{l}\text { UL } \\
\text { (5) }\end{array}$ & $\begin{array}{l}\text { SA } \\
(10)\end{array}$ & $\begin{array}{l}L \\
(5)\end{array}$ & $\begin{array}{l}\mathrm{DE} \\
(5)\end{array}$ & $\begin{array}{l}\text { AS } \\
\text { (5) }\end{array}$ & $\begin{array}{l}\text { SC } \\
(5)\end{array}$ & $\begin{array}{l}\text { UN } \\
(5)\end{array}$ & $\begin{array}{l}\text { OC } \\
(10)\end{array}$ & $\begin{array}{l}\text { DP } \\
(20)\end{array}$ & $\begin{array}{l}\text { GD } \\
\text { (10) }\end{array}$ & Total \\
\hline 22-Marine terrace of Punta Licosa & 4 & 1 & 4 & 4 & 4 & & 2 & 4 & 4 & 4 & 4 & 4 & 3,6 \\
\hline 24-Sandstones of San Marco & 3 & 4 & 4 & 4 & 4 & 2 & 4 & 4 & 4 & 4 & 4 & 4 & 3,8 \\
\hline 26-Baia Arena & 2 & 4 & 4 & 4 & 4 & 2 & 4 & 3 & 2 & 1 & 1 & 2 & 2,45 \\
\hline 27-Ripe Rosse cliff & 4 & 1 & 4 & 3 & 4 & 2 & 4 & 3 & 1 & 3 & 4 & 3 & 3,1 \\
\hline 33-Punta Tresino & 4 & 2 & 4 & 3 & 4 & 2 & 4 & 3 & 1 & 3 & 4 & 3 & 3,2 \\
\hline 37-Alento River & 1 & 4 & 2 & 4 & 4 & 2 & 4 & 3 & 1 & 2 & 1 & 4 & 2,5 \\
\hline 38-Elea-Velia & 3 & 4 & 4 & 4 & 4 & 2 & 4 & 4 & 4 & 4 & 4 & 4 & 3,8 \\
\hline 92-grotta di Cala Fetente & 3 & 1 & 2 & 2 & 4 & 2 & 4 & 3 & 2 & 3 & 2 & 2 & 2,35 \\
\hline 93-Cliff of Capo Palinuro & 3 & 1 & 1 & 2 & 4 & 2 & 4 & 3 & 1 & 3 & 4 & 3 & 2,75 \\
\hline 94-coastal caves of Camerota & 3 & 1 & 2 & 2 & 4 & 2 & 4 & 4 & 2 & 3 & 2 & 2 & 2,4 \\
\hline 96-coast from White Cove to Punta Infreschi & 3 & 1 & 2 & 2 & 4 & 2 & 4 & 4 & 1 & 3 & 4 & 2 & 2,75 \\
\hline 97-Fossil dunes of Palinuro & 2 & 4 & 3 & 4 & 4 & 2 & 4 & 1 & 4 & 3 & 1 & 3 & 2,7 \\
\hline 98-Tyrrhenian deposits of Palinuro & 2 & 4 & 3 & 4 & 4 & 2 & 4 & 1 & 4 & 4 & 1 & 3 & 2,8 \\
\hline 102-Canyon of Marcellino river & 4 & 1 & 1 & 2 & 4 & 2 & 4 & 1 & 2 & 2 & 1 & 1 & 1,9 \\
\hline 104-coastal caves of Cala Cefalo & 3 & 1 & 1 & 2 & 4 & 2 & 4 & 3 & 2 & 3 & 2 & 3 & 2,4 \\
\hline
\end{tabular}


Table 2. List of selected coastal geosites and indicators used to assess their touristic value. The geosite number is from Aloia et al. [61]. The number below each indicator represents its relative weight.

\begin{tabular}{|c|c|c|c|c|c|c|c|c|c|c|c|c|c|c|}
\hline \multicolumn{15}{|c|}{ Educational Use of the Geosites } \\
\hline Indicator & $\begin{array}{l}\mathrm{V} \\
(\mathbf{1 0})\end{array}$ & $\begin{array}{l}\mathrm{AC} \\
(\mathbf{1 0 )}\end{array}$ & $\begin{array}{l}\text { UL } \\
(5)\end{array}$ & $\begin{array}{l}\text { SA } \\
(10)\end{array}$ & $\begin{array}{c}L \\
(5) \\
\end{array}$ & $\begin{array}{l}\mathrm{DE} \\
(5)\end{array}$ & $\begin{array}{r}\text { AS } \\
(5)\end{array}$ & $\begin{array}{l}\text { SC } \\
(15)\end{array}$ & $\begin{array}{l}\text { UN } \\
\text { (10) }\end{array}$ & $\begin{array}{l}\text { OC } \\
(5)\end{array}$ & $\begin{array}{l}\text { IP } \\
(\mathbf{1 0})\end{array}$ & $\begin{array}{l}\text { EL } \\
(5)\end{array}$ & $\begin{array}{c}\text { RA } \\
(5)\end{array}$ & Total \\
\hline 22-Marine terrace of Punta Licosa & 4 & 1 & 4 & 4 & 4 & 2 & 4 & 4 & 4 & 4 & 4 & 1 & 4 & 3,05 \\
\hline 24-Sandstones of San Marco & 3 & 4 & 4 & 4 & 4 & 2 & 4 & 4 & 4 & 4 & 3 & 1 & 4 & 3,15 \\
\hline 26-Baia Arena & 2 & 4 & 4 & 4 & 4 & 2 & 4 & 3 & 2 & 1 & 1 & 1 & 4 & 2,4 \\
\hline 27-Ripe Rosse cliff & 4 & 1 & 4 & 3 & 4 & 2 & 4 & 3 & 1 & 3 & 4 & 1 & 4 & 2,65 \\
\hline 33-Punta Tresino & 4 & 2 & 4 & 3 & 4 & 2 & 4 & 3 & 1 & 3 & 4 & 1 & 4 & 2,75 \\
\hline 37-Alento River & 1 & 4 & 2 & 4 & 4 & 2 & 4 & 3 & 1 & 2 & 1 & 1 & 4 & 2,25 \\
\hline 38-Elea-Velia & 3 & 4 & 4 & 4 & 4 & 2 & 4 & 4 & 4 & 4 & 4 & 1 & 4 & 3,25 \\
\hline 92-grotta di Cala Fetente & 3 & 1 & 2 & 2 & 4 & 2 & 4 & 3 & 2 & 3 & 1 & 1 & 3 & 2,05 \\
\hline 93-Cliff of Capo Palinuro & 3 & 1 & 1 & 2 & 4 & 2 & 4 & 3 & 1 & 3 & 4 & 1 & 3 & 2,25 \\
\hline 94-coastal caves of Camerota & 3 & 1 & 2 & 2 & 4 & 2 & 4 & 4 & 2 & 3 & 3 & 1 & 3 & 2,3 \\
\hline 96-coast from White Cove to Punta Infreschi & 3 & 1 & 2 & 2 & 4 & 2 & 4 & 4 & 1 & 3 & 3 & 1 & 3 & 2,25 \\
\hline 97-Fossil dunes of Palinuro & 2 & 4 & 3 & 4 & 4 & 2 & 4 & 1 & 4 & 3 & 2 & 1 & 4 & 2,65 \\
\hline 98-Tyrrhenian deposits of Palinuro & 2 & 4 & 3 & 4 & 4 & 2 & 4 & 1 & 4 & 4 & 2 & 1 & 4 & 2,75 \\
\hline 102-Canyon of Marcellino river & 4 & 1 & 1 & 2 & 4 & 2 & 4 & 1 & 2 & 2 & 2 & 1 & 3 & 2 \\
\hline 104-coastal caves of Cala Cefalo & 3 & 1 & 1 & 2 & 4 & 2 & 4 & 3 & 2 & 3 & 2 & 1 & 4 & 2,15 \\
\hline
\end{tabular}


The high didactic value of these sites makes them suitable for educational activities addressed to the diffusion of environmental knowledge. With this in mind, we consulted all the available literature data about these sites and tried to "translate" the main basic geological concepts to a wider audience, not necessarily having a geological background. Taking into account the suggestions of UNESCO [73] and Macadam [24], we tried to avoid the use of geological jargon, dumbing down the concepts but without losing their scientific integrity. We used photos, sketches, maps, and 3-D reconstructions accompanied by short and simple sentences to explain our messages. In particular, for each discussed topic, we designed explanatory panels that can serve as a guideline [74-76] for both touristic guides and science teachers at different educational levels. We conceived the panels with a design that could be readable on the most common electronic devices (e.g., smartphone, tablets) thus making the panels available for the users during the entire trip.

The 3-D views have been obtained from detail scale digital terrain models (DTM). The latter includes Light Detection and Ranging (Lidar) data obtained by the Italian Minister of the Environment. Lidar data have been imported in a Geographic Information System (GIS) software, Arcgis 10.7@ (Redlands, CA, USA), to derive a hillshade map that has been managed by means of the ArcScene module to obtain the 3-D views. The latter have been obtained by applying a 3-times vertical exaggeration and have been rotated, with respect the north, to obtain the point of view that allows the best appreciation of the coastal landforms.

\section{Results}

\subsection{Geosites Selection}

The location of the geosites selected among those listed in the Geopark official list is reported in Figure 2. The results of the application of the Brilha method [68] are reported in Table 1 (educational use of the geosites) and Table 2 (touristic use of the geosites). Moreover, regarding the accessibility indicator (AC), the selected geosites are often placed along the coasts (geosites n. 92, 93, 94, 96, 102 and 104) and they can be reached only by boats, so we have considered distances indicated by Brilha [68] as distances from the closest harbour. As a result of the evaluation, three geosites gained the highest scores in both indexes, which are the geosite n. 22-Marine terrace of Punta Licosa, geosite n. 24-Sandstones of San Marco, and geosite n. 38-Elea-Velia. Consequently, we have selected these three geosites and planned the educational geoitinerary. 


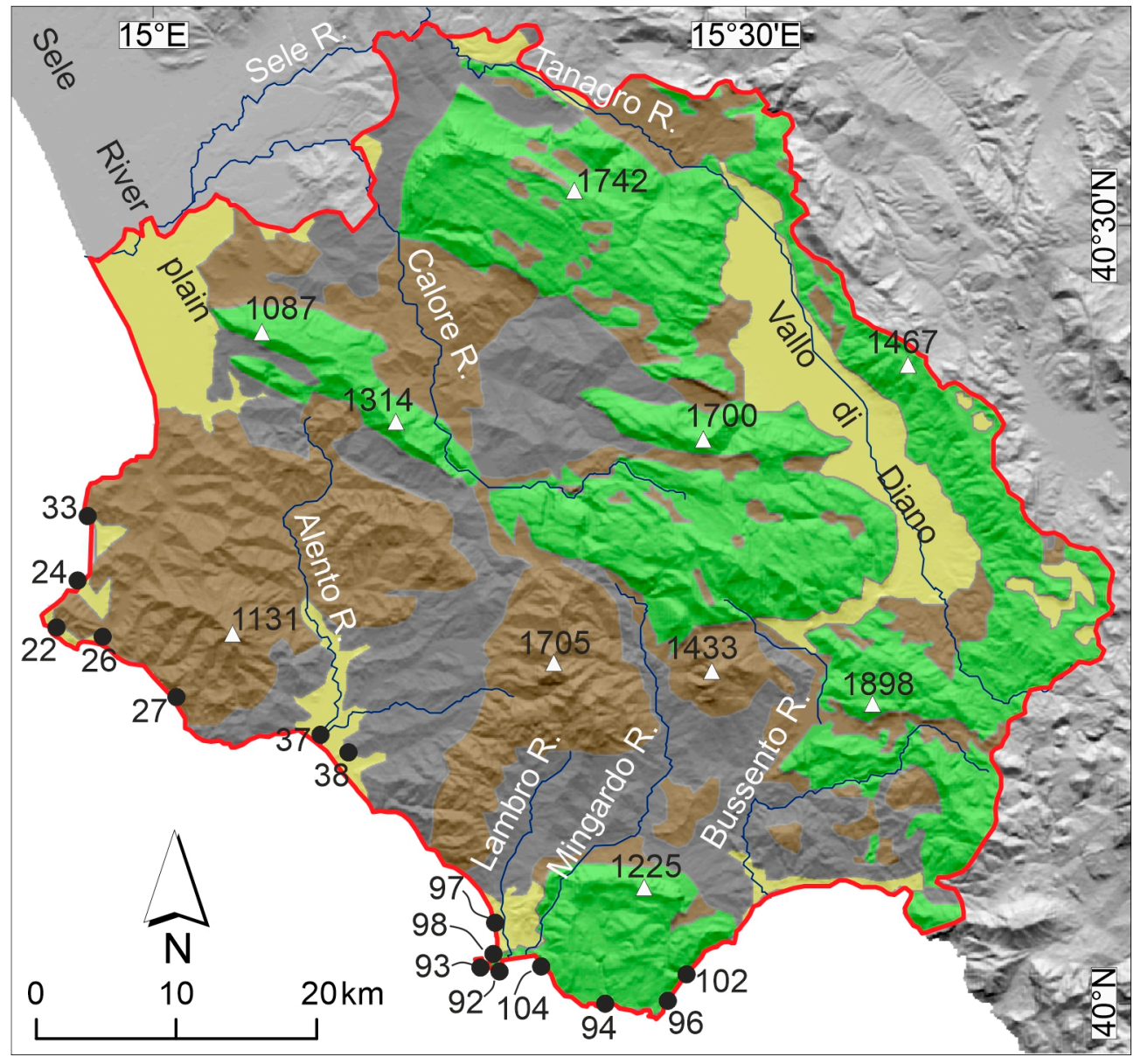

Figure 2. Locations of 15 geosites placed along the Geopark coast and listed in Tables 1 and 2. Numbers refer to geosite numbers reported in both tables.

\subsection{Geoitinerary Topics}

The sites we have chosen are exemplary to explain the sea level fluctuations that occurred on Earth over the last 250,000 years [77-79] in response to the climate cyclicity (eustatic sea level fluctuations). As shown in Figure 3, during this time interval, the sea level has fluctuated between "High" and "Low" conditions, with variations in the range of about $100 \mathrm{~m}$. The "High" conditions relate to "Interglacial" periods, meaning that climate conditions were similar to the present one or even warmer and more humid. In these periods, ice caps and continental glaciers melted and reduced their extensions, causing the rise of sea level at a global scale. The "Low" conditions are correlated with moments (Glacial periods) when the climate was colder and dryer than the present one. During these periods, the ice masses extended, and the sea level dropped down to $120 \mathrm{~m}$ below the present sea level.

Looking at the figure, we can observe that 130,000 years ago (Last Interglacial) the sea level was higher than the present one, at the Last Glacial Maximum (20,000 years ago) it moved down to $-120 \mathrm{~m}$ and, from then, it started rising up to the present altitude. These relative motions of the sea level obviously caused significant variations in coastal environments, such as the shifting of the coastline position.

We think that these simple concepts on the extreme dynamicity of the coastal environment and on the past climate changes should be fundamental for the education of each citizen, from students to administrators and politicians. We planned the geoitinerary trying to explain these main sea level fluctuations, choosing one site for each peak described in Figure 3. 
The San Marco site has preserved the evidence of the Penultimate Interglacial, the Licosa Cape site shows forms and deposits of the Last Interglacial, and finally the Elea-Velia site allows us to discuss on the Post-glacial sea level rise.

\section{Climate change and sea level fluctuations}

The last 960,000 years of the Earth's history have been characterised by strong climate changes. Several cold (glacial) and warm (interglacial) periods alternated, with a ciclicity of about 100,000 years. During the repeated glacial and interglacial periods, the cyclic formation and melting of glaciers and sea ice resulted in alternated trapping of freshwater and its releasing to the oceans. Thus, the changing ice volumes were accompanied by major sea level fluctuations in the range of about 100 metres.

Sea level curve for the last 250,000 years

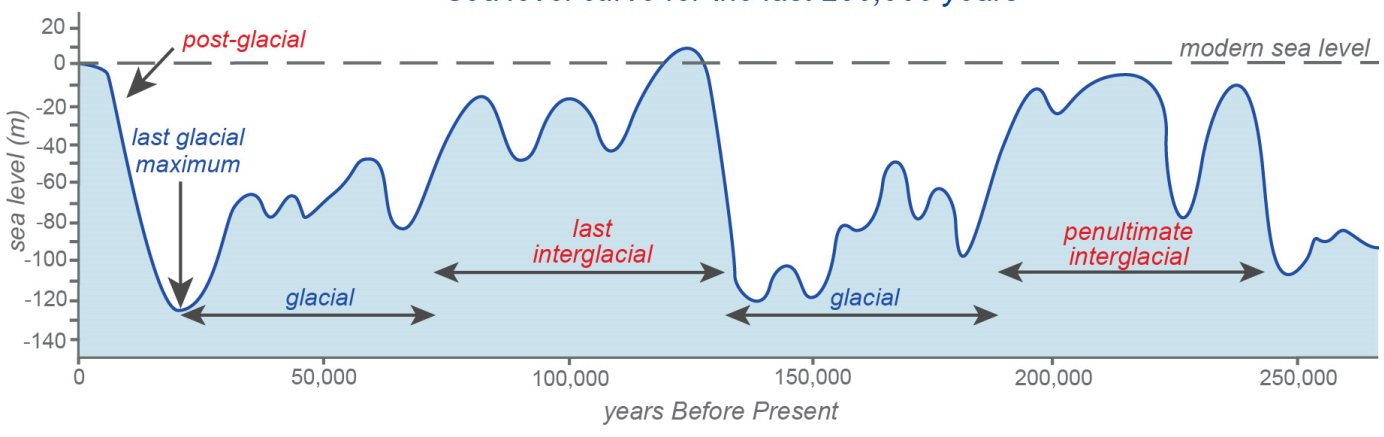

A sea level curve shows the amount of the sea level fluctuations that accompanied the climatic fluctuations. In the curve, the warm, or interglacial, climatic stages correspond to high values of the sea level, while the cold, glacial stages to low sea level values.

In the last 250,000 years, the sea level raised to values close to the modern one (the $0 \mathrm{~m}$ value in the curve above) during two main interglacial periods, namely in the penultimate interglacial, which occurred around 200,000 years ago, and in the last interglacial. During the last interglacial, the sea level peaked to values even higher than the modern one around 130,000 years ago. Drops of the sea level down to $120 \mathrm{~m}$ were recorded during the glacial stages, including the last glacial maximum, which occurred 20,000 years ago. Since then, that is in the post-glacial stage, the sea level has been rising to the modern value.

Figure 3. Explanatory panel on eustatic sea level fluctuations for the last 250,000 years. The sea level curve was redrawn and modified after References [78,79].

\subsection{The Geoitinerary}

The geoitinerary consists of two parts: the first part starts from the center of San Marco village and reaches the Licosa cape. The second part focuses on the archeological site of Elea-Velia. It needs at least two days, and the journey from the first stop to the last one implies a transfer by car $(32 \mathrm{~km})$. The first part of the geoitinerary includes a nice walk of about $3 \mathrm{~km}$ from the San Marco harbourharbour to the Licosa cape, with no significant altitude variations (Figure 4). 


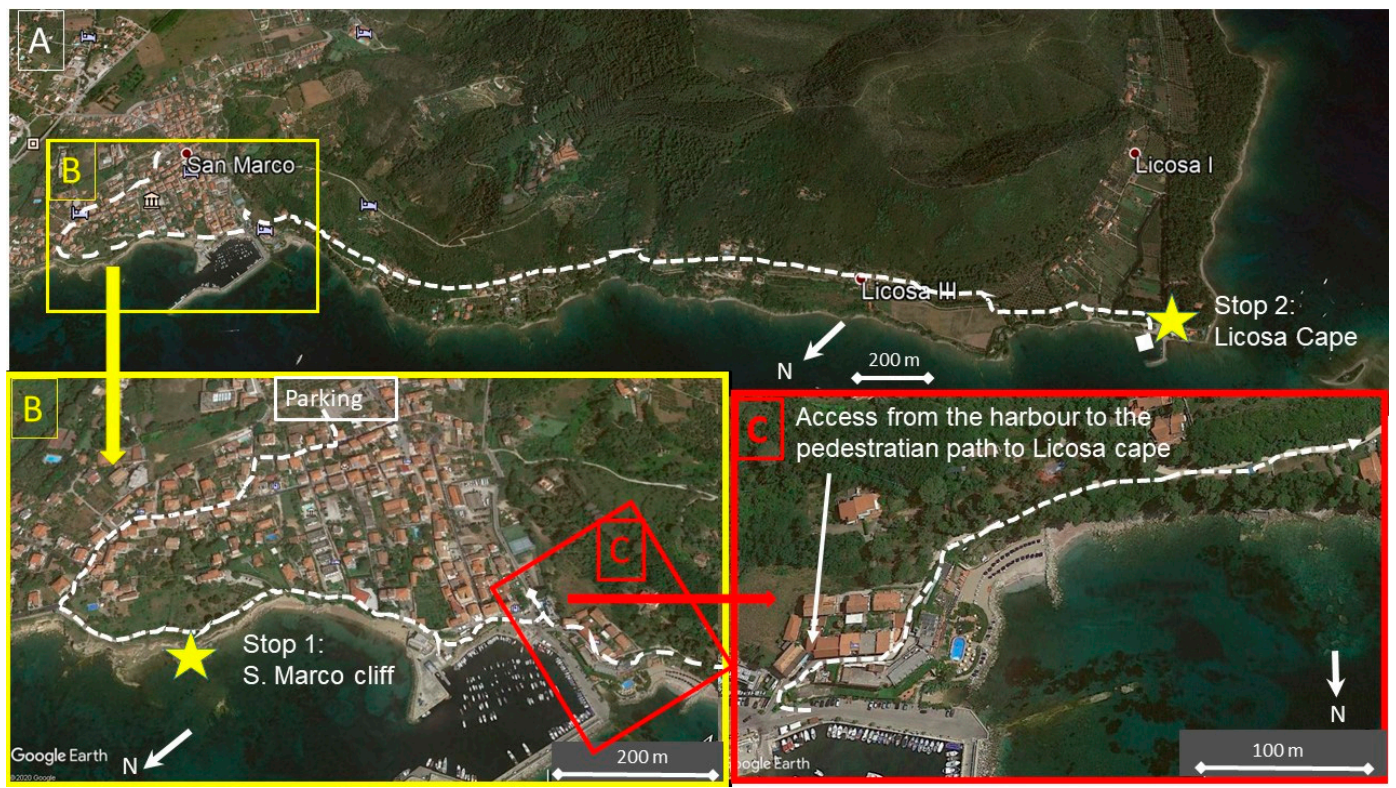

Figure 4. The itinerary of the first day: (A) location of stop 1 and 2; (B) the walk from the center of San Marco, down to the coastal cliff and the harbour; (C) detail of the access to the walk from the San Marco harbour towards Licosa cape.

\subsubsection{First Part: the San Marco Sea Cliff and the Licosa Cape Stops}

Main topic: evolution of rocky coasts

Contents: sea cliff, marine deposits, marine terrace

Stop 1: San Marco Sea Cliff and Marine Terrace

After parking in the center of the San Marco village, the tourist may direct towards the sea. The pedestrian pathway along the cliff offers a good occasion to explain what a coastal cliff is, how it forms, and how it evolves during time (Figure 5). Following the tracks, it is possible to reach the sea, observing the cliff and the wave-cut platform located at its foot. The latter is well exposed if the sea is flat and in low tide conditions. It is also possible to observe that above the platform, there are several blocks and masses, fallen from the cliff: this site may be useful to understand that a cliff is a dynamic, not static environment, which is moving backward ("retreating") over time. The lower part of Figure 5 (coastal hazard) explains how the normal evolution of a cliff may interact with human activity causing risk conditions for both human properties and lives.

This site is also representative because it preserves the best exposure along the coast of the Geopark of ancient coastal marine sediments related to the Penultimate Interglacial (around 200,000 years ago [55]) with well-preserved sedimentary structures (Figure 6). Looking at the cliff, even a casual tourist may catch the spectacular geometric design drawn by the nature on this rock.

In particular, the cliff is made up of ancient coastal sands, which are now uplifted and form a wide depositional terrace over which the village of San Marco is built (Figure 7). The good exposure of well-preserved sedimentary structures makes this site significant for educational purposes for geological science students. They may come in touch with sandstones and their textures and may observe different kinds of sedimentary structures, testifying for a submerged beach environment. Instead, around 200,000 years ago, the area now occupied by the village of San Marco was invaded by the sea, becoming a gulf, and sands were deposited at the sea bottom. These sands now lie at 15-20 m above the sea level, an altitude higher than the eustatic sea level related to the Penultimate Interglacial (Figure 3). This means that the land moved upward (tectonic uplift) with respect to the sea and the deposited sands emerged, forming the San Marco marine terrace. Geologists name this kind of marine terrace as "raised marine terrace". 


\section{The San Marco sea cliff}

What is a sea cliff (or coastal cliff, or maritime cliff)?

It is defined as a steep rocky slope, often sub-vertical and sometimes overhanging, that rises precipitously from the sea. A sea cliff is formed by the impact, at its base, of plunging waves and debris picked up by the breaking waves

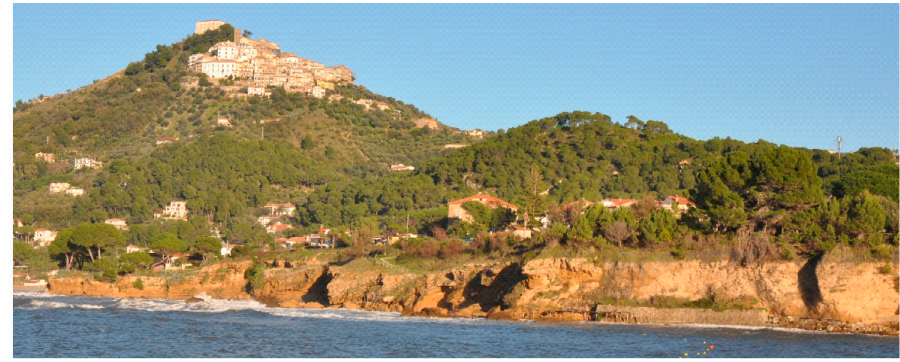

$\rightarrow$

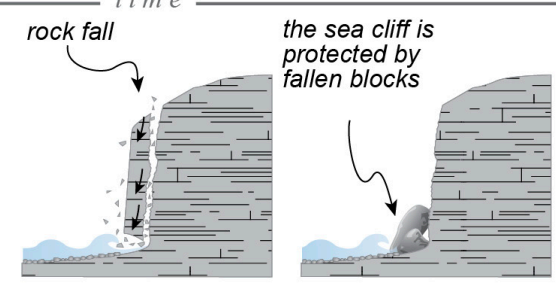

renewed erosion of the sea cliff

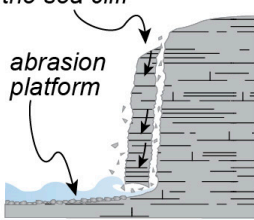

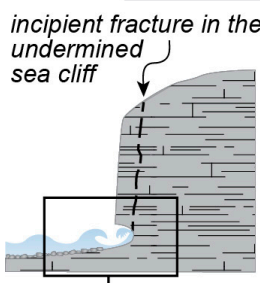
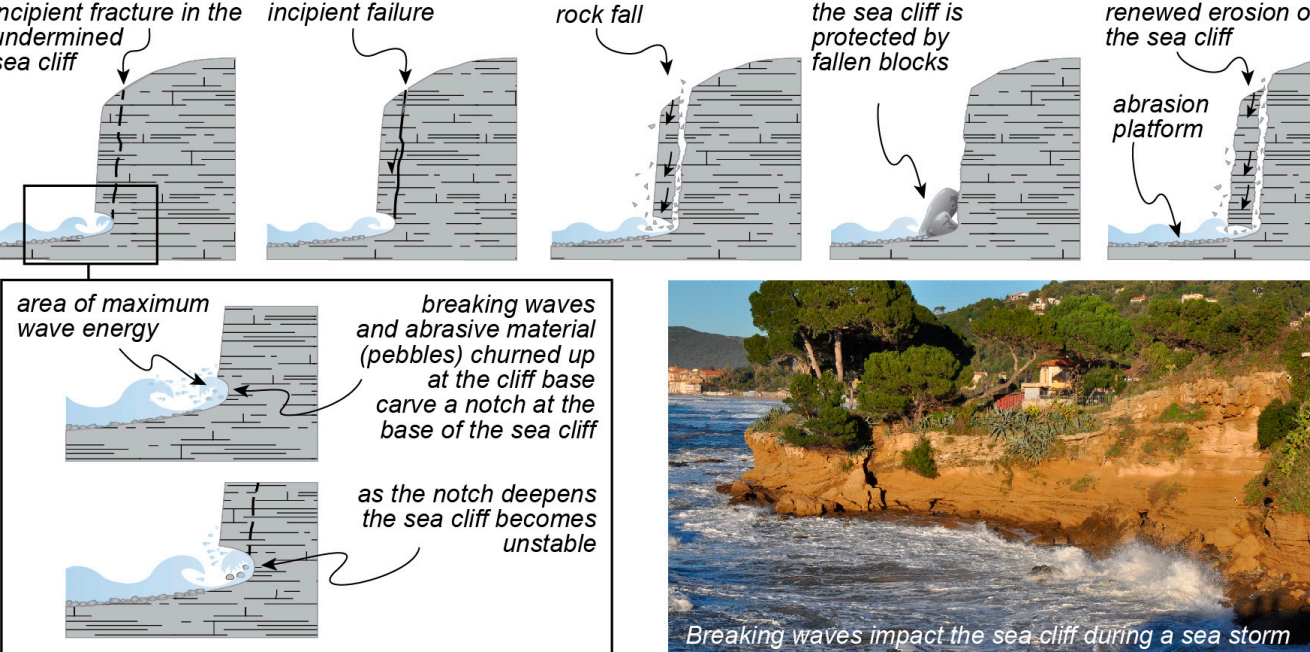

Day by day, with repeated sea storms, the breaking waves erode the base of the sea cliff. The upper, overhanging part of the sea cliff is made unstable and breaks dowm. The large fallen blocks rest at the base of the sea cliff until they are destroyed by wave action, while the smaller rock fragments are carried away by the sea.

Prolonged erosion makes the sea cliff move back, or retreat. As the sea cliff retreats, an abrasion platform is carved at the cliff base.

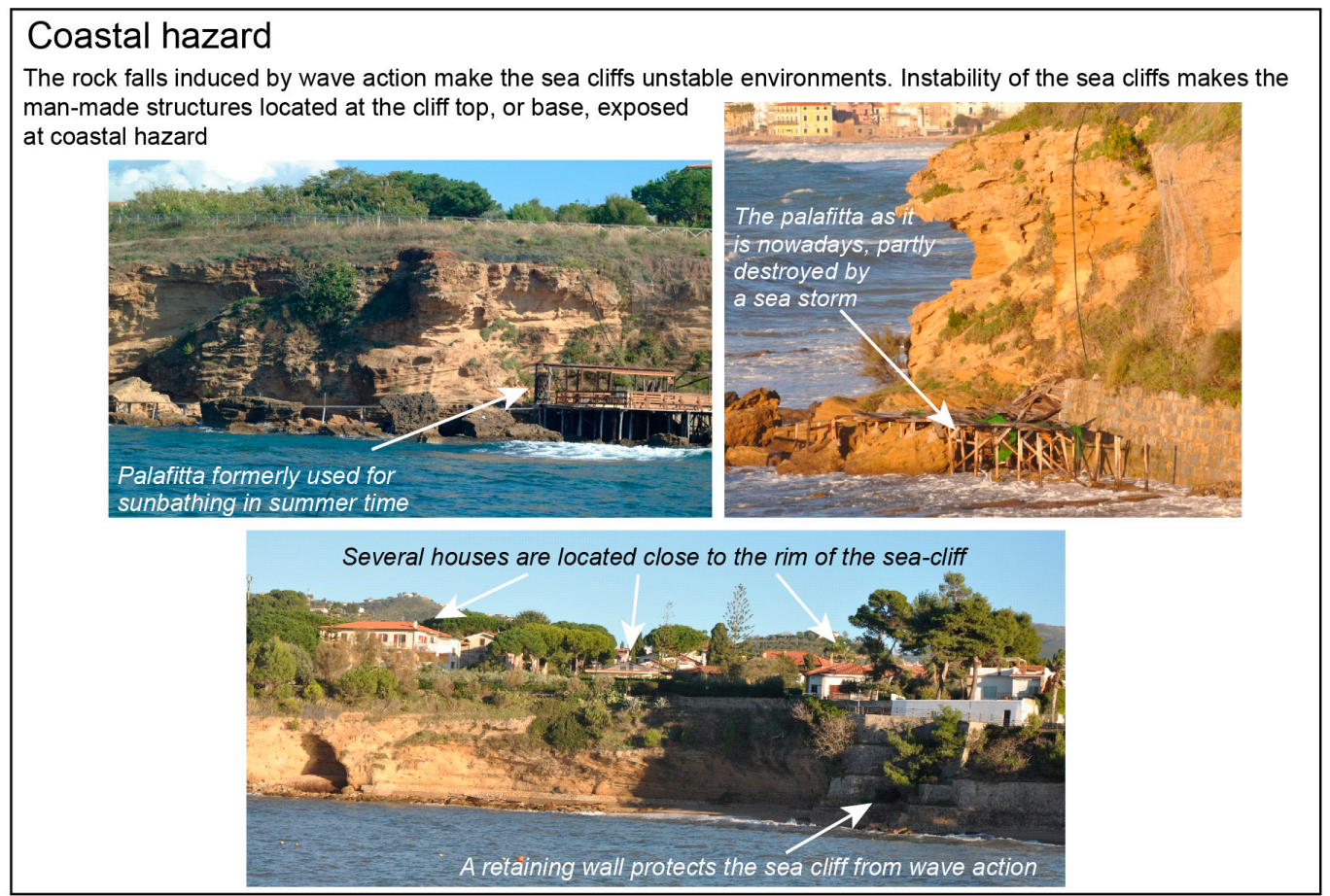

Figure 5. Explanatory panel on coastal cliff formation and evolution. 
The San Marco sandstones
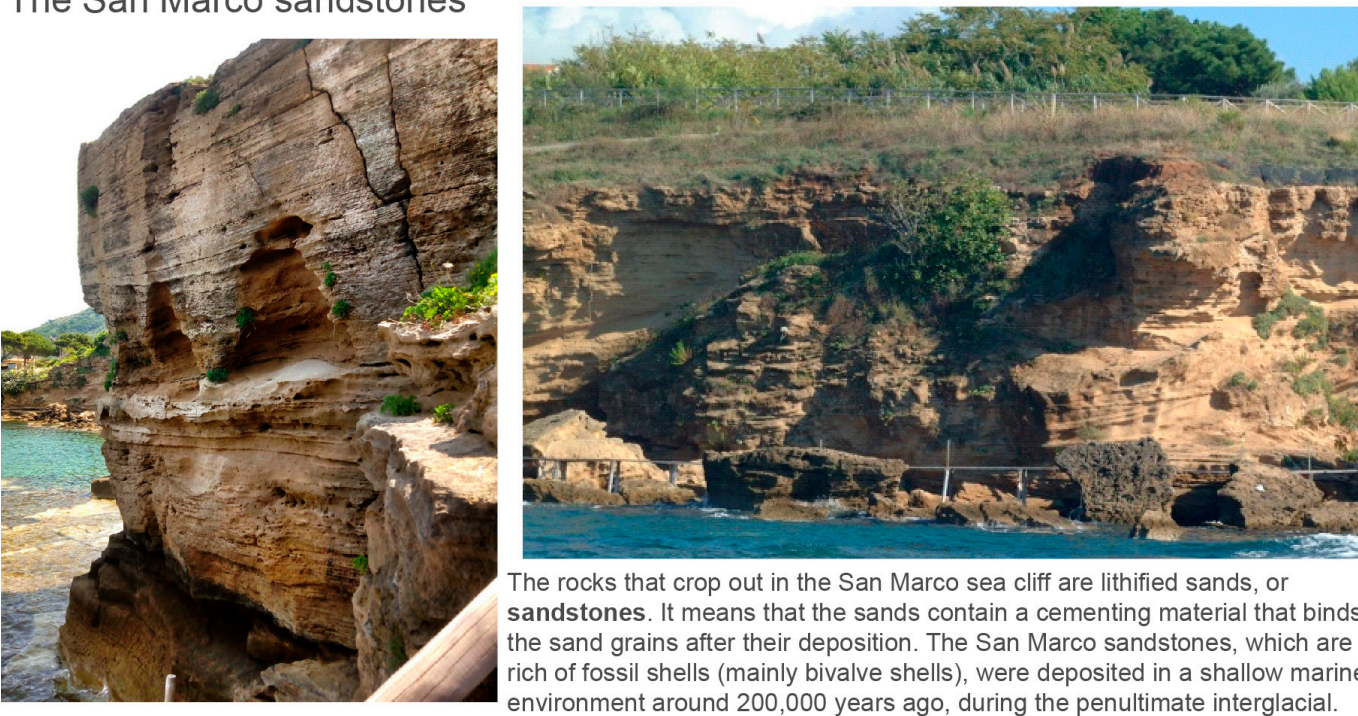

The rocks that crop out in the San Marco sea cliff are lithified sands, or sandstones. It means that the sands contain a cementing material that binds the sand grains after their deposition. The San Marco sandstones, which are rich of fossil shells (mainly bivalve shells), were deposited in a shallow marine environment around 200,000 years ago, during the penultimate interglacial.

During the penultimate interglacial the sea level rose and invaded the land, forming a deep bay in the area where nowadays the San Marco village is located. In that bay the San Marco sandstones were sedimented, while sea cliffs and abrasion platforms were sculpted in the adjacent rocky headlands.
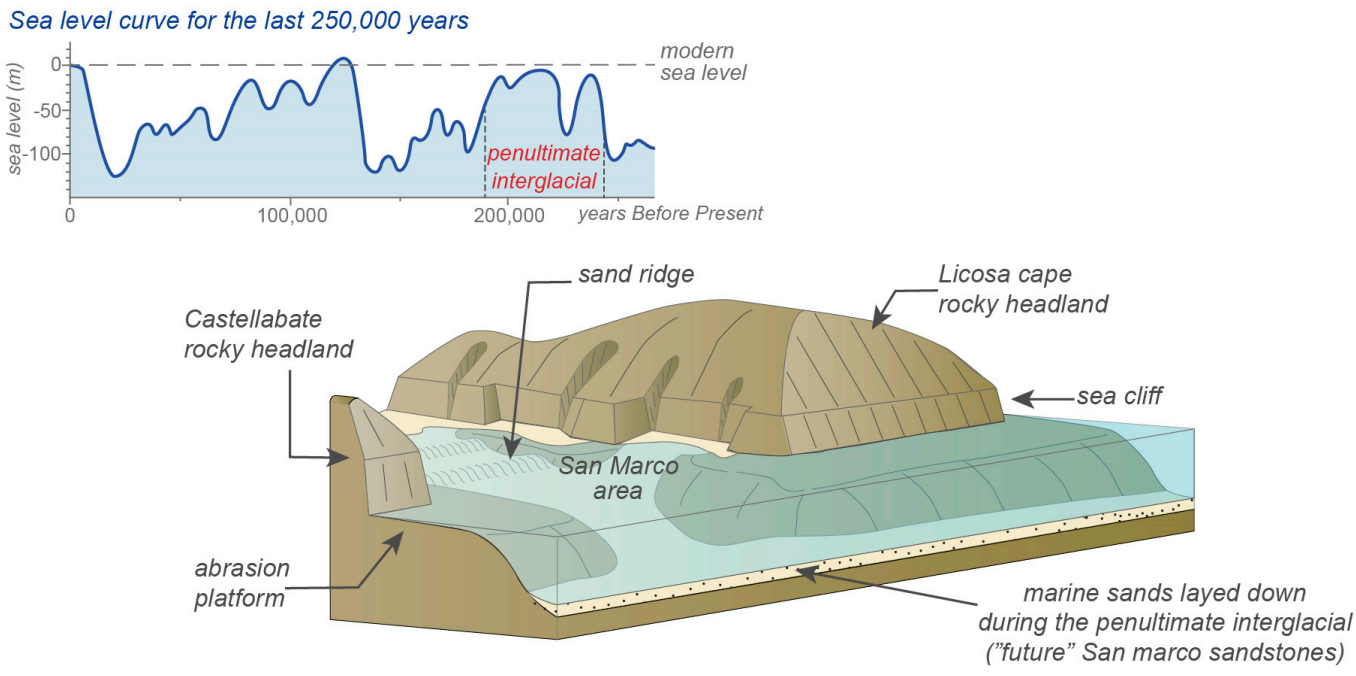

The San Marco sandstones are characterised by a peculiar layering named cross bedding, which consists of sets of beds that are inclined to the main horizontal bedding. The cross bedding of the San Marco sandstones developed by the migration of submerged sand ridges (similar to desert dunes) constructed by the action of storm waves on the sea bottom at the time of their deposition.
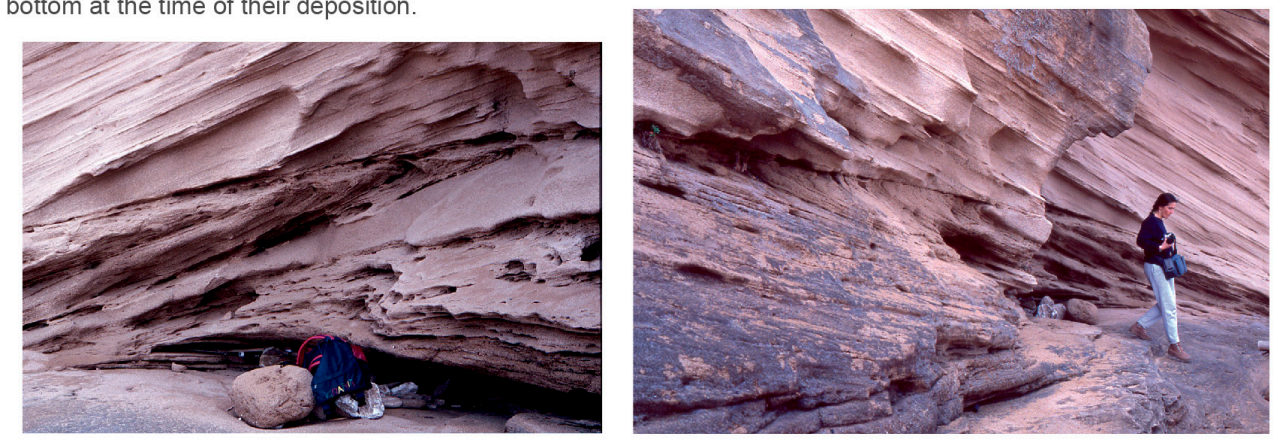

Figure 6. Explanatory panel on the ancient marine deposits outcropping in the San Marco sea cliff. 

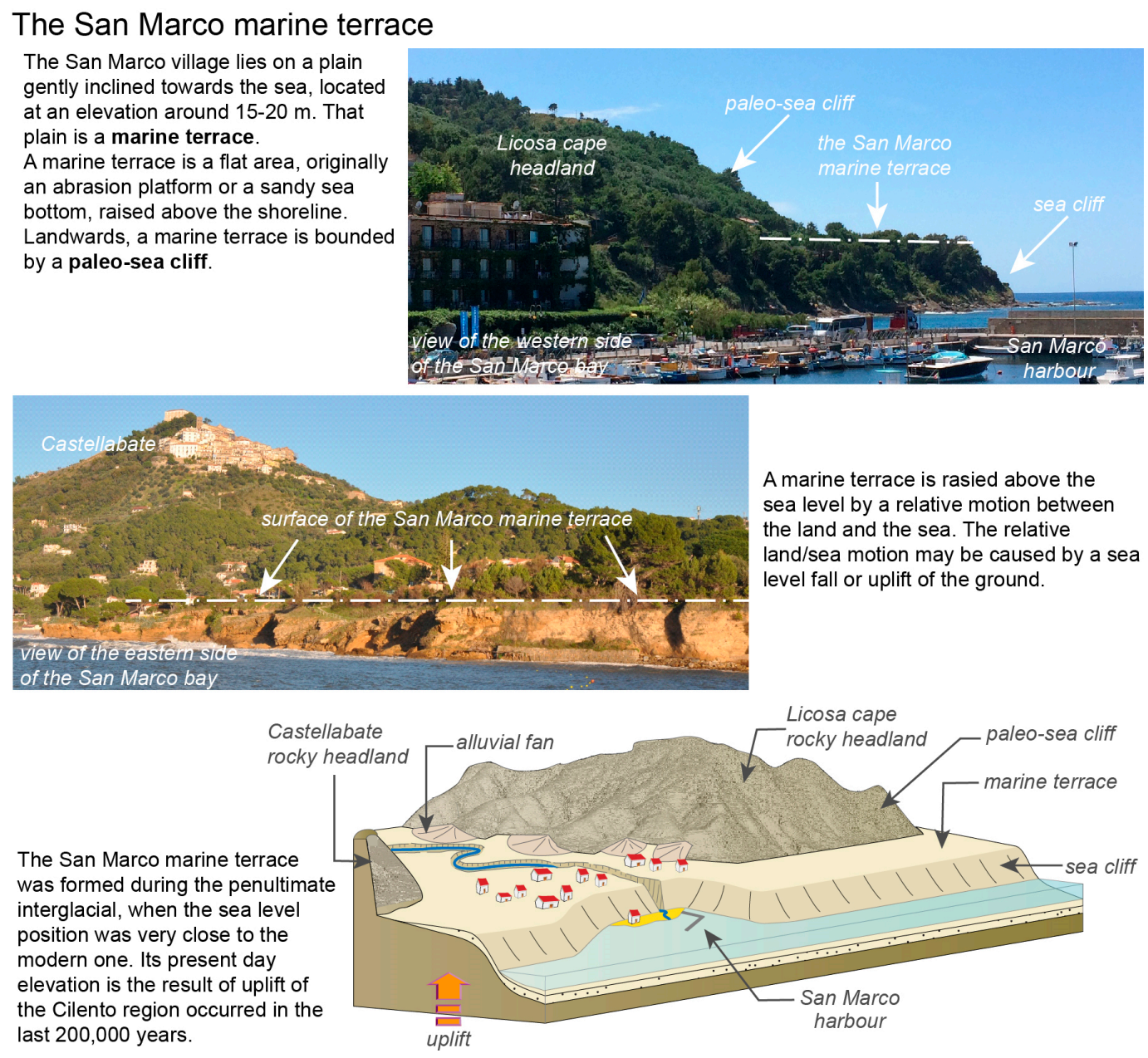

Figure 7. Explanatory panel on the San Marco raised marine terrace.

\section{Stop 2: The Licosa Cape}

From the harbour of San Marco, the geoitinerary continues towards the Licosa cape. The path starts behind the Approdo Hotel and, after a $1 \mathrm{~h}$ walking (Figure 3), it reaches the Licosa cape, where it is possible to have a spectacular view on the little island of Leucosia, so named after one of the mythologic mermaids which distracted Ulysses during its navigation.

The Licosa cape is characterized by the presence of a wide marine terrace (Figure 8) carved by the sea on the Miocene bedrock. It represents an ancient abrasion platform, formed during the Last Interglacial period, when the sea was 6-8 $\mathrm{m}$ higher than the present one (Figure 3). Differently from the San Marco terrace, in this case, the altitude of the terrace coincides with that of the sea level (eustatic level; Figure 3) meaning that the land was not uplifted. Geologists refer to this kind of marine terrace as an "eustatic terrace". Along the southern part of the promontory, it is possible to observe that the terrace is locally covered by marine deposits mainly made up of fossil corals and red algae. Geologist were able to define the age of these fossils by means of complex geochemical techniques (in particular, U/Th dating, see Iannace et al. [57] for further details). 
The last interglacial marine terrace of the Licosa cape

A wide marine terrace surronds the Licosa cape headland. The marine terrace is located between about 5 and 10 metres above the sea level, an elevation range similar to that of the sea level rise recorded around 100,000 years ago, during the last interglacial.
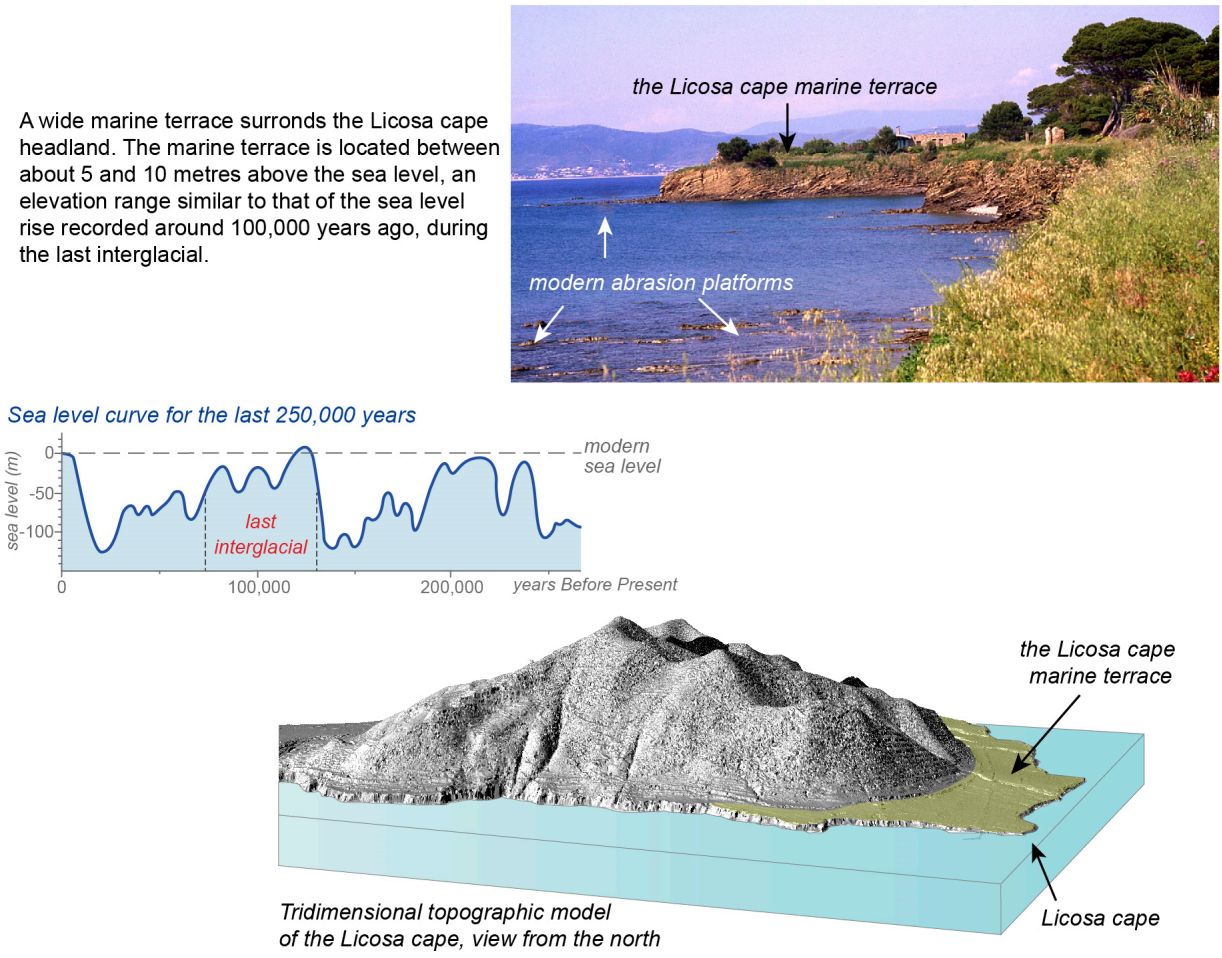

The abrasion platform of the Licosa marine terrace is locally covered by a fossil algal mat composed of algae entrapping sand grains, which provide a nice picture of the Licosa raised sea bottom.
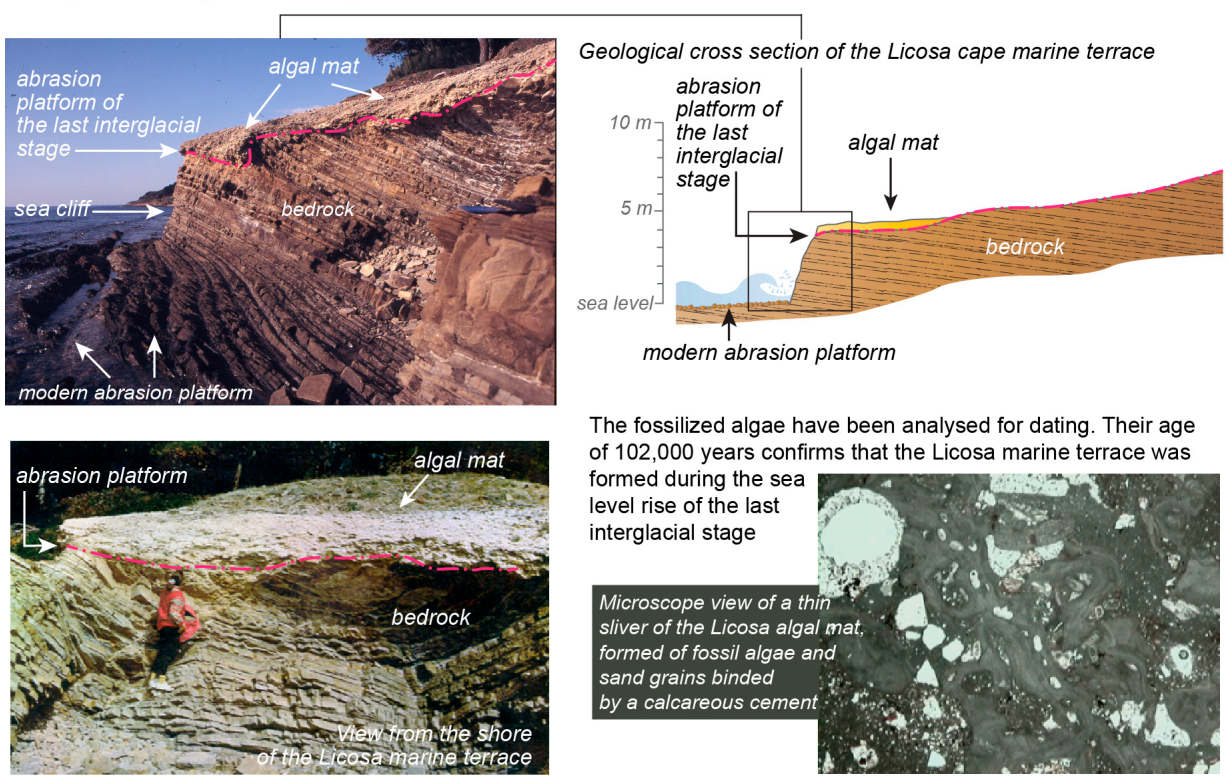

Figure 8. Explanatory panel on the Licosa cape eustatic marine terrace.

\subsubsection{The Elea-Velia Geo-Archaeological Site}

Main Topic: evolution of flat coasts

Contents: coastal progradation; alluvial fan; human-environment interaction

The Archaeological Park of Elea-Velia lies in the alluvial-coastal plain of the Fiumarella River and can be reached from San Marco driving towards South the road named SS267 (Figure 9). 


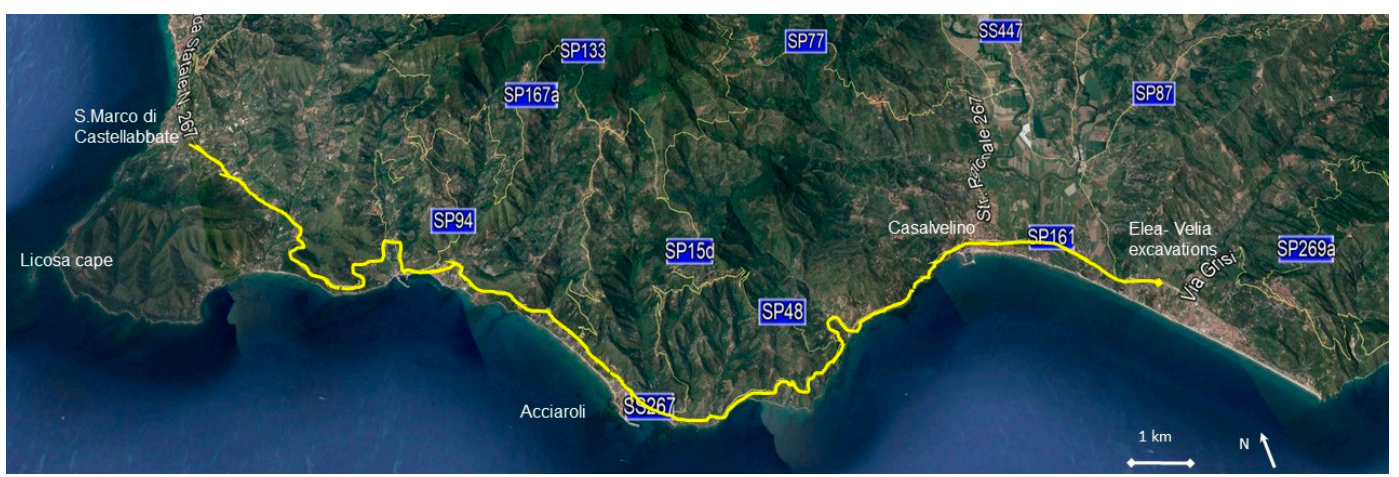

Figure 9. Transfer from San Marco to the Archaeological Park of Elea-Velia.

The Graeco-Roman town of Elea-Velia was founded by the Phoceans in the VI century BC and developed as a Roman town up to the IV century AD when it was abandoned due to both harbour infilling and burial of most of the lower quarters by alluvial deposits [70,71]. For these reasons, this site is explicative of two geomorphological processes: the coastal progradation and the alluvial fan deposition. Both phenomena interacted with human activity from the town foundation up to its abandonment. Within the Archaeological tour of the Park, we suggest two stops which allow for an understanding of the paleogeographical evolution of the area as well as the main environmental changes of the last millennia, including the repeated events of flooding, which caused the burying of the ancient town. Although it is one of the most important touristic attractions of the Geopark, with a number of visitors ranging from 25,000 to 35,000 per year in the period 1996-2018 [80], this peculiar geoarchaeological aspect has not yet been the object of any educational project.

Stop 1: The Acropolis

From the Acropolis it is possible to have a wide view on the flat territory surrounding the hill, down to the sea. In this part of the tour, we will focus on what happened during the Postglacial period, when the sea level was rising from $-120 \mathrm{~m}$ (Last Glacial Maximum) up to its present position. Looking at the eustatic sea level curve of the last 10,000 years (Figure 10), we may observe that there is a variation in the rate of sea level rise at around 7000 years ago. Before that moment, the curve is very steep, suggesting a very rapid sea level rise that resulted in a general submersion of flat coastal areas. For this reason, when the Greeks colonized the territory, the Acropolis hill was a promontory bounded by two gulfs, that extended in place of the present Alento (to the NW) and Fiumarella (to the SE) plains [48]. Active sea-cliffs were shaped along the rocky coasts, whereas in front of the flat alluvial-coastal plains, sand ridges isolated lagoon environments that were suitable places for landing.

Why is the Acropolis hill now located hundreds of meters inland with respect to the present coastline? The answer is in the complex interaction between coastal processes and sea level fluctuations [81-83]. From 7000 years ago up to now, the rate of sea level rise decreased and was compensated by the incessant sediment supply from inland (Figure 9). For this reason, the coastline started to move towards the sea, and this phenomenon is called "coastal progradation". 
Coastline changes in the Elea-Velia area

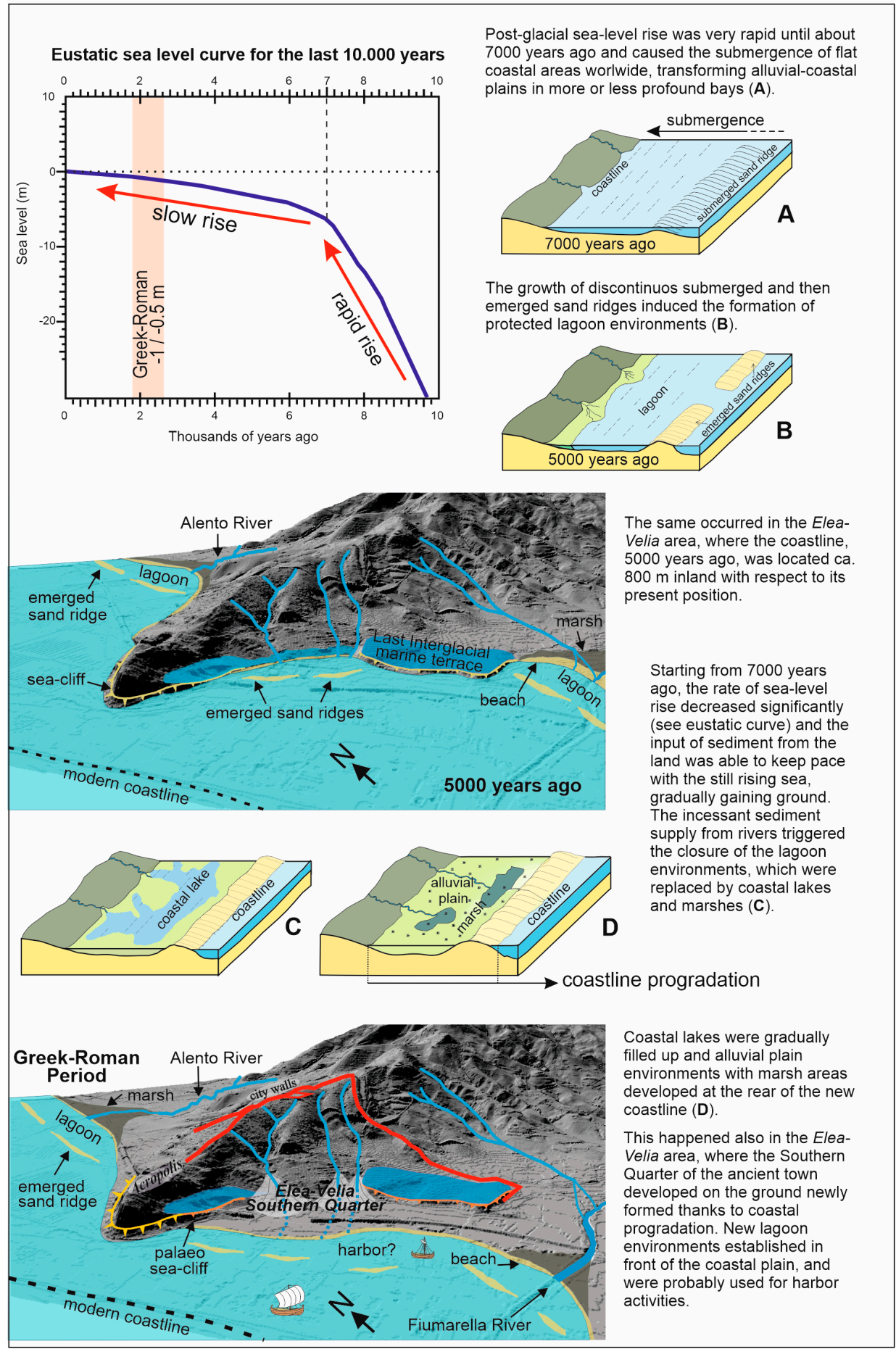

Figure 10. Explanatory panel on paleogeographic condition of the Elea-Velia site before and during the Greek colonization.

\section{Stop 2: Via di Porta V}

This stop allows the visitors to have a look at the sequence of alluvial fan deposits that damaged the structures of the Southern Quarter all along the life of the Graeco-Roman town. The alluvial deposits came from the erosion of the stream catchments cutting the slopes at the rear of the Southern Quarter, within the town perimeter (Figure 11). The sedimentological characteristic of the alluvial deposits exposed in the section (massive, badly sorted, and poorly stratified pebbles, sands, and silts) 
clearly indicates that these alluvial events occurred mainly as debris flow, i.e., the water transported high quantity of debris, behaving as a high-density fluid. The intensive fan deposition caused the town abandonment after several phases of restoration. From that moment, a few other floods affected the area up to the $\mathrm{V}$ century AD, when flooding was definitively interrupted [72,83].

\section{The alluvial fans that buried Elea-Velia}

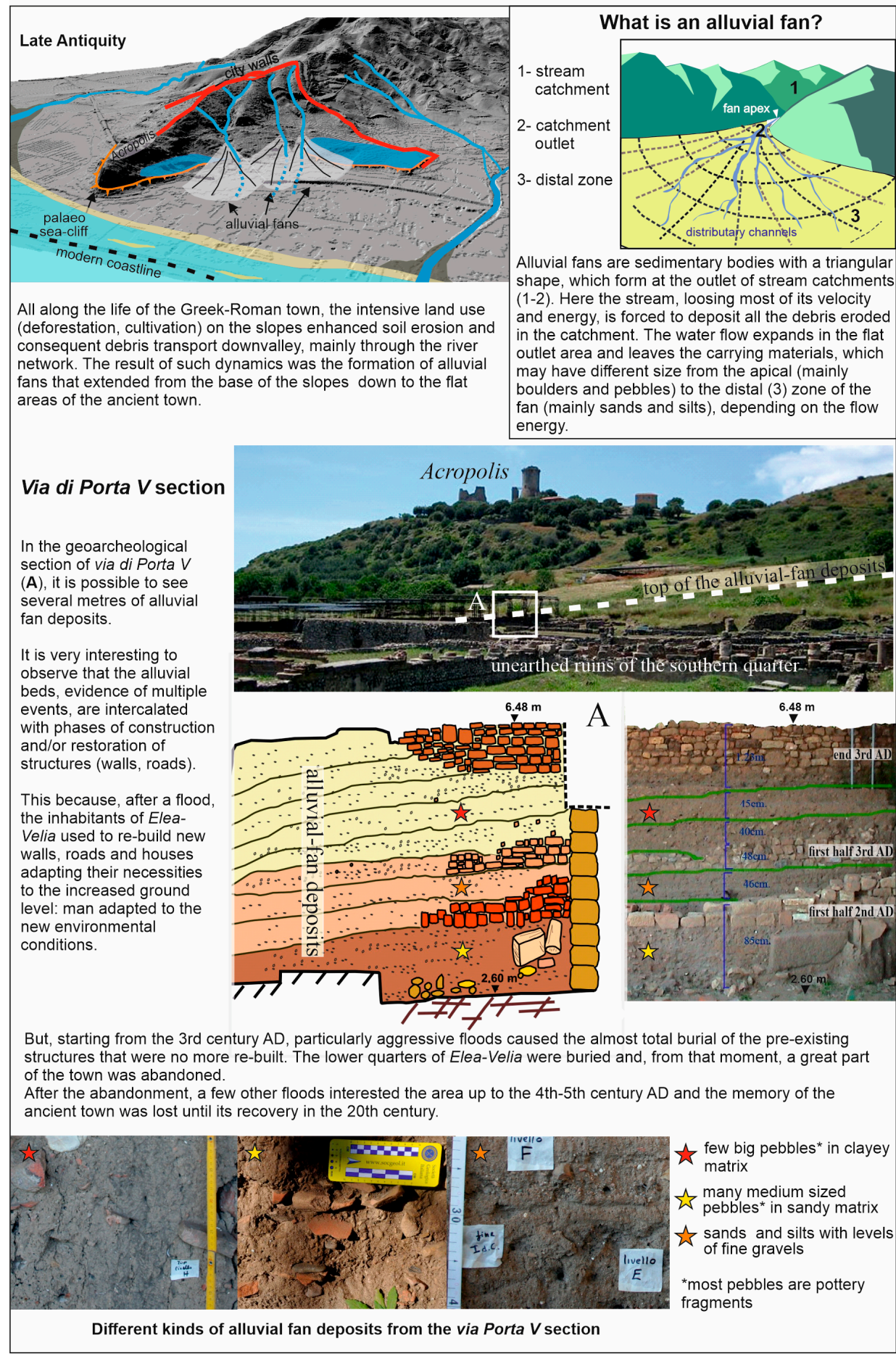

Figure 11. Explanatory panel on the alluvial events that caused the burying of Elea-Velia. 


\section{Discussion and Conclusions}

The objective of our work was to provide an example of how geosites, and in particular those with high didactic value, may be used for educational purposes. Bearing in mind our aim, we chose those that are the "best sites" in the coastal belt of the Geopark and built a didactic path. Unfortunately, up to now, the educational itinerary in the area is still a missing topic, and when consulting the Geopark web page it is possible to find only general information about the geology of the Geopark, the wildlife, and the vegetation. The Geopark website, in fact, suggests only one poorly detailed itinerary in the karst area of the Bussento river [84]. In such a context, the paper herein and one recently published [35] address the potential educational value of geosites in the Cilento, Vallo di Diano, and Alburni Geopark, and they may be used as examples of how to use geosites to divulge geological knowledge to a wide audience. By adopting a similar geological approach, didactic routes may be organized within the Geopark, choosing the best sites for various environmental topics.

International tourism is a fundamental economic resource for the coastal areas of the Cilento, Vallo di Diano, and Alburni Geopark [65,66]. In fact, the economy of the coastal areas is mainly based on international tourism, although it is mainly focused during summertime, and the preferred touristic destinations are the beaches and the archeological sites of Elea-Velia and Paestum [66,67]. Considering that any development of the Cilento, Vallo di Diano, and Alburni Geopark should be based on the enhancement of local resources through the active cooperation of all local actors [67], our work may be an incitement for the Geopark administrators to develop educational activity as a source for touristic interest. The development of such an activity might also contribute to extending the tourist presence beyond summertime, over most of the year.

To analyze the potential of the geoitinerary and to highlight possible activities addressed to its efficiency and effective use, we also defined the strengths, weaknesses, opportunities, and threats through the SWOT analysis, whose results are reported in Table 3.

We strongly believe that increasing the base geological knowledge of each citizen, from the student to the politician or the administrator, may contribute to increasing the awareness in respect to the evolution of our planet and its environmental systems. Indeed, to achieve integrated management of resources and spaces in a coastal area, it is critical to understand the possible change patterns, which differ substantially in the two environmental scenarios we have focused on, i.e., the sea cliffs and coastal plains. For instance, given the widespread and in some instances dense use of coastal land, it is crucial for people to become acquainted with the risk under which properties, people, and their economic activities are eventually posed by coastal recession and instabilities in both the short and long terms. The scenarios that we selected as sites for visits represent meaningful examples of the instability of both rocky coasts under the current, meteorologically-driven coastal dynamics, and low-lying coastal areas exposed to the impact of future sea level rise. Now more than ever before, it is mandatory to generate public awareness about geology and environmental conditions related to global climate change. Issues such as coastal erosion and submergence of coastlines are becoming popular and, in this respect, evidence of the striking environmental impact of the relatively-subdued sea level rise that occurred in the Elea-Velia area appears as a meaningful exemplification of possible future change in comparable scenarios.

Geotourism may be one of the most useful tools to spread knowledge on the dynamicity of the natural environment. However, to reach this goal, individual and/or group visitors should get knowledge in advance through guide boards and educational or informational image data. With our work, we tried to achieve such an objective and our wish is that the explanatory material we designed may constructively support geopark guides and teachers aiming at promoting the Geopark area and spreading geological knowledge, respectively, through geotourism. 
Table 3. Results of the SWOT (strengths, weaknesses, opportunities and threats) analysis about the development of Geotourism in the Cilento, Vallo di Diano, and Alburni Geopark.

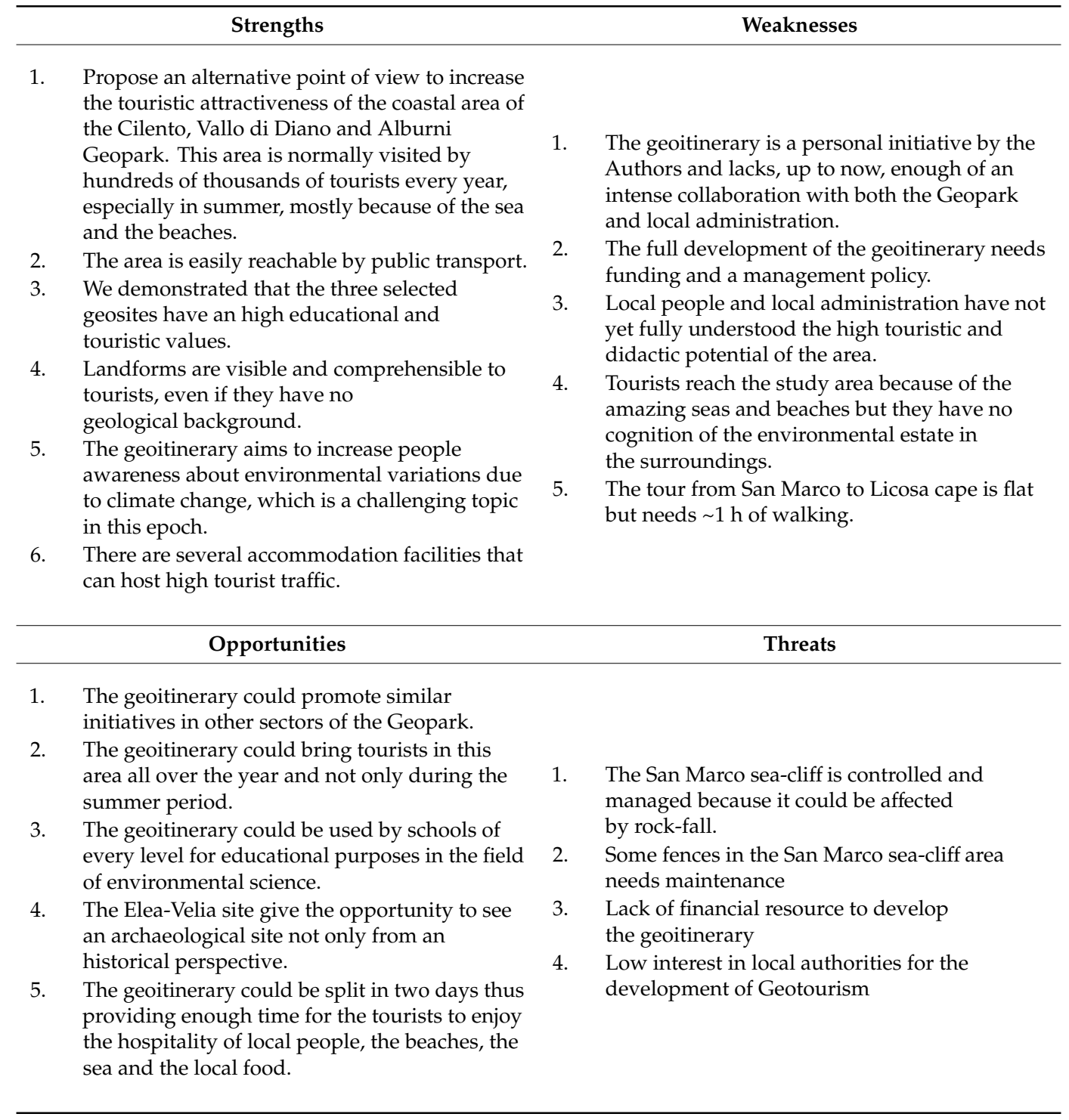

Finally, we intended for the interdisciplinary perspective we propose for the Elea-Velia archaeological site to serve as a contribution to increasing its touristic interest. We selected Elea-Velia to suggest that, for an archaeological site, the availability of geological information which integrates information on historical or cultural issues through the explanation of the environmental conditions that existed during the human frequentation may provide the tourist with a more comprehensive view of the interaction between human activities (agriculture, commerce, etc.) and the natural landscape. This may be a new approach for the valorization of archaeological sites. Archaeological heritage is one of the most important economic resources of Italy and, particularly, of the Campania region, where numerous archaeological sites ranging in value from global to national and regional interest are located. Most of those sites, besides telling of history, architecture, and figurative art, bear the legacy of geological and/or geomorphological processes and human-environment interaction. Despite this, there is still no effort, even in the most important sites such as Pompeii and Herculaneum excavations, to divulge the natural aspect of the archaeological sites $[85,86]$. As we believe that learning from the past is crucial to understand the present and future environmental crisis, we have put the attention on the "other stories" that an archaeological site may narrate to its visitors. 
Author Contributions: Conceptualization, N.S., A.A. and E.R.E.; methodology, N.S. and E.V.; software E.V.; validation, N.S., A.A. and E.R.E.; formal analysis, V.A.; investigation: San Marco Licosa area: N.S., A.A. and E.V.; Elea-Velia: V.A. and E.R.E.; writing-original draft preparation, N.S. and E.V.; writing—review and editing, N.S., A.A., E.V. and E.R.E.; visualization, A.A., E.R.E. and E.V.; supervision, N.S. All authors have read and agreed to the published version of the manuscript.

Funding: This research received no external funding.

Acknowledgments: We wish to thank three anonymous reviewers whose suggestions helped us to improve the manuscript.

Conflicts of Interest: The authors declare no conflict of interest.

\section{References}

1. UNESCO Global Geoparks Operational Guidelines. Available online: www.unesco.org (accessed on 29 April 2020).

2. Henriques, M.H.; Brilha, J.B. UNESCO Global Geoparks: A strategy towards global understanding and sustainability. Episodes 2017, 40, 349-355. [CrossRef]

3. Dowling, R. Geotourism's Global Growth. Geoheritage 2010, 3, 1-13. [CrossRef]

4. Global Geoparks Network (GGN). Guidelines and Criteria for National Geoparks Seeking UNESCO's Assistance to Join the Global Geoparks Network (GGN) (January 2014). France: European Geoparks Network. Available online: http://www.europeangeoparks.org/wp-content/uploads/2012/03/Geoparks_ Guidelines_Jan2014.pdf (accessed on 29 April 2020).

5. Woo, K.S. Qualification and prospect of national and global geoparks in Korea. J. Geol. Soc. Korea 2014, 50, 3-19. [CrossRef]

6. Koh, Y.-K.; Oh, K.-H.; Youn, S.-T.; Kim, H.-G. Geodiversity and geotourism utilization of islands: Gwanmae Island of South Korea. J. Mar. Isl. Cult. 2014, 3, 106-112. [CrossRef]

7. Joyce, B.; Brohl, M. Geological and geomorphological features of Australia: How our geosites can be used in geoparks and geotourism to promote better understanding of our geological heritage and as a tool for public education. In Proceedings of the Inaugural Global Geotourism Conference: Discover the Earth Beneath Our Feet, Fremantle, Australia, 17-20 August 2008.

8. Bloise, A.; Catalano, M.; Critelli, T.; Apollaro, C.; Miriello, D. Naturally occurring asbestos: Potential for human exposure, San Severino Lucano (Basilicata, Southern Italy). Environ. Earth Sci. 2017, 76, 648. [CrossRef]

9. Gozzard, J.R. WA Coast-Rottnest Island Digital Datasets; Geological Survey of Western Australia: Perth, Australia, 2011.

10. Dowling, R.; Newsome, D. Chapter 1: Geotourism: Definition, characteristics and international perspectives. In Handbook of Geotourism; Edward Elgar Publishing: Cheltenham, UK, 2018; pp. 1-22.

11. Ólafsdóttir, R.; Tverijonaite, E. Geotourism: A Systematic Literature Review. Geosciences 2018, 8, 234. [CrossRef]

12. Justice, S. UNESCO Global Geoparks, Geotourism and Communication of the Earth Sciences: A Case Study in the Chablais UNESCO Global Geopark, France. Geosciences 2018, 8, 149. [CrossRef]

13. Zeppel, H. Climate change and tourism in the Great Barrier Reef Marine Park. Curr. Issues Tour. 2012, 15, 287-292. [CrossRef]

14. Zeppel, H.; Beaumont, N. 2011 Climate change and Australian tourism: A research bibliography. ACSBD Working Paper No. 1. In Climate Change and Australian Tourism; Australian Centre for Sustainable Business and Development, University of Southern Queensland: Springfield Central, Australia, 2011.

15. Scott, D.; Hall, C.M.; Stefan, G. Tourism and Climate Change; Informa UK Limited: London, UK, 2012.

16. Wang, L.; Tian, M.; Wang, L. Geodiversity, geoconservation and geotourism in Hong Kong Global Geopark of China. Proc. Geol. Assoc. 2015, 126, 426-437. [CrossRef]

17. Rutherford, J.; Newsome, D.; Kobryn, H.; Jessica, R.; David, N.; Halina, K. Interpretation as a Vital Ingredient of Geotourism in Coastal Environments: The Geology of Sea Level Change, Rottnest Island, Western Australia. Tour. Mar. Environ. 2015, 11, 55-72. [CrossRef] 
18. Castedo, R.; Paredes, C.; De La Vega-Panizo, R.; Santos, A.P.; Santos, R.D.L.V.A.A.P. The Modelling of Coastal Cliffs and Future Trends. In Hydro-Geomorphology_Models and Trends; IntechOpen: London, UK, 2017; pp. 53-78.

19. Valiela, I. Global Coastal Change; Blackwell Publishing: Oxford, UK, 2006; p. 367.

20. Bird, E. Coastal Geomorphology: An Introduction, 2nd ed.; John Wiley \& Sons: New York, NY, USA, 2008 ; p. 436.

21. Trenhaile, A.S. Chapter 2 Climate change and its impact on rock coasts. Geol. Soc. Lond. Mem. 2014, 40, 7-17. [CrossRef]

22. Nicholls, R.J.; Cazenave, A. Sea-Level Rise and Its Impact on Coastal Zones. Science 2010, 328, 1517-1520. [CrossRef] [PubMed]

23. Iinternational Panel on Climate Change. Climate Change 2014: Mitigation of Climate Change. In Contribution of Working Group III to the Fifth Assessment Report of the Intergovernmental Panel on Climate Change; Cambridge University Press (CUP): Cambridge, UK, 2014.

24. Macadam, J. Geoheritage: Getting the message across. What message and to whom? In Geoheritage. Assessment, Protection, and Management; Reynard, E., Brilha, J., Eds.; Elsevier: Amsterdam, The Netherlands, 2018; pp. 267-288.

25. Mazzoli, S.; Helman, M. Neogene patterns of relative plate motion for Africa-Europe: Some implications for recent central Mediterranean tectonics. Geol. Rundsch. 1994, 83, 464-468. [CrossRef]

26. Turco, E.; Macchiavelli, C.; Mazzoli, S.; Schettino, A.; Pierantoni, P. Kinematic evolution of Alpine Corsica in the framework of Mediterranean mountain belts. Tectonophysics 2012, 579, 193-206. [CrossRef]

27. Sartori, R. The Tyrrhenian back-arc basin and subduction of the Ionian lithosphere. Episodes 2003, 26, $217-221$. [CrossRef]

28. Ciarcia, S.; Mazzoli, S.; Vitale, S.; Zattin, M. On the tectonic evolution of the Ligurian accretionary complex in southern Italy. GSA Bull. 2011, 124, 463-483. [CrossRef]

29. Ascione, A.; Ciarcia, S.; Di Donato, V.; Vitale, S.; Mazzoli, S. The Pliocene-Quaternary wedge-top basins of southern Italy: An expression of propagating lateral slab tear beneath the Apennines. Basin Res. 2011, 24, 456-474. [CrossRef]

30. Mazzoli, S.; Szaniawski, R.; Mittiga, F.; Ascione, A.; Capalbo, A. Tectonic evolution of Pliocene-Pleistocene wedge-top basins of the southern Apennines: New constraints from magnetic fabric analysis. Can. J. Earth Sci. 2012, 49, 492-509. [CrossRef]

31. Gray, J.M. Geodiversity: Developing the paradigma. Proc. Geol. Assoc. 2008, 119, 287-298. [CrossRef]

32. Ruban, D.A. Quantification of geodiversity and its loss. Proc. Geol. Assoc. 2010, 121, 326-333. [CrossRef]

33. Santangelo, N.; Santo, A. Endokarst processes in the Alburni massif (Campania, southern Italy): Evolution of ponors and hydrogeological implications. Z. Geomorphol. 1997, 41, 229-246.

34. Santangelo, N.; Romano, P.; Santo, A. Geo-itineraries in the Cilento Vallo di Diano Geopark: A Tool for Tourism Development in Southern Italy. Geoheritage 2014, 7, 319-335. [CrossRef]

35. Valente, E.; Santo, A.; Guida, D.; Santangelo, N. Geotourism in the Cilento, Vallo di Diano and Alburni UNESCO Global Geopark (Southern Italy): The Middle Bussento Karst System. Resources 2020, 9, 52. [CrossRef]

36. Vitale, S.; Ciarcia, S.; Mazzoli, S.; Zaghloul, M. Tectonic evolution of the 'Liguride' accretionary wedge in the Cilento area, southern Italy: A record of early Apennine geodynamics. J. Geodyn. 2011, 51, 25-36. [CrossRef]

37. Vitale, S.; Ciarcia, S. Tectono-stratigraphic and kinematic evolution of the southern Apennines/Calabria-Peloritani Terrane system (Italy). Tectonophysics 2013, 583, 164-182. [CrossRef]

38. Vitale, S.; Ciarcia, S.; Fedele, L.; Tramparulo, F.D.; Vitale, S.; Sabatino, C.; Lorenzo, F.; D’Assisi, T.F. The Ligurian oceanic successions in southern Italy: The key to decrypting the first orogenic stages of the southern Apennines-Calabria chain system. Tectonophysics 2019, 750, 243-261. [CrossRef]

39. Vitale, S.; Ciarcia, S. Tectono-stratigraphic setting of the Campania region (southern Italy). J. Maps 2018, 14, 9-21. [CrossRef]

40. Vitale, S.; Amore, O.; Ciarcia, S.; Lo Schiavo, L.; Santangelo, N.; Tramparulo, F. Itinerario 11- Cilento settentrionale. In Guide Geologiche Regionali-Campania e Molise; Calcaterra, D., D'Argenio, B., Ferranti, L., Pappone, G., Petrosino, P., Eds.; Società Geologica Italiana: Rome, Italy, 2016; pp. 69-80, ISBN 9788894022728.

41. Geological Map of Italy at Scale 1:50000, Sheet 502-Agropoli. Available online: http://www.isprambiente. gov.it/Media/carg/502_AGROPOLI/Foglio.html (accessed on 30 April 2020). 
42. Geological Map of Italy at Scale 1:50000, Sheet 503-Vallo. Available online: http://www.isprambiente.gov.it/ Media/carg/503_VALLO/Foglio.html (accessed on 30 April 2020).

43. Geological Map of Italy at Scale 1:50000, Sheet 519-Capo Palinuro. Available online: http://www. isprambiente.gov.it/Media/carg/519_CAPO_PALINURO/Foglio.html (accessed on 30 April 2020).

44. Vitale, S.; Ciarcia, S.; Mazzoli, S.; Iannace, A.; Torre, M. Structural analysis of the 'Internal' Units of Cilento, Italy: New constraints on the Miocene tectonic evolution of the southern Apennine accretionary wedge. C. R. Geosci. 2010, 342, 475-482. [CrossRef]

45. Cello, G.; Mazzoli, S. Apennine tectonics in southern Italy: A review. J. Geodyn. 1998, 27, 191-211. [CrossRef]

46. Romano, P. La distribuzione del Pleistocene marino lungo le coste della Campania: Stato delle conoscenze e prospettive di ricerca. Stud. Geol. Camert. 1992, 1, 265-269.

47. Cinque, A.; Romano, P.; Rosskopf, C.; Santangelo, N.; Santo, A. Morfologie costiere e depositi quaternari tra Agropoli e Ogliastro Marina (Cilento-Italia Meridionale). II Quat. 1994, 7, 3-16.

48. Cinque, A.; Rosskopf, C.; Barra, D.; Campajola, L.; Paolillo, G.; Romano, P. Nuovi dati stratigrafici e cronologici sull'evoluzione recente della piana del fiume Alento (Cilento, Campania). II Quat. 1995, 8, 323-338.

49. Iannace, A.; Romano, P.; Santangelo, N.; Santo, A.; Tuccimei, P. The OIS 5c along Licosa cape promontory (Campania region, Southern Italy). Z. Geomorphol. 2001, 45, 307-319.

50. Esposito, C.; Filocamo, F.; Marciano, R.; Romano, P.; Santangelo, N.; Scarciglia, F.; Tuccimei, P. Late Quaternary shorelines in southern Cilento (Mt. Bulgheria): Morphostratigraphy and chronology. II Quat. 2003, 16, 3-14.

51. Antonioli, F.; Cinque, A.; Ferranti, L.; Romano, P. Emerged and Submerged Quaternary Marine Terraces of Palinuro Cape (Southern Italy). Mem. Descr. Carta Geol. d'It 1994, 52, 293-319.

52. Antonioli, F.; Ascione, A.; Cinque, A.; Ferranti, L.; Romano, P. Coastal and Underwater Geomorphology of Capo Palinuro Area, Guidebook to the field-Sea trip. In Proceedings of the Guide for Excursion, International Meeting on Underwater Geology, Rome, Italy, 8-10 June 1994.

53. Brancaccio, L.; Cinque, A.; Romano, P.; Rosskopf, C.; Russo, F.; Santangelo, N.; Santo, A. L'evoluzione delle pianure costiere della Campania: Geomorfologia e neotettonica. Mem. Soc. Geogr. Ital. 1995, 53, 313-336.

54. Ascione, A.; Romano, P. Vertical movements on the eastern margin of the Tyrrhenian extensional basin. New data from Mt. Bulgheria (Southern Apennines, Italy). Tectonophysics 1999, 315, 337-356. [CrossRef]

55. Santangelo, N.; Santo, A.; Guida, D.; Lanzara, R.; Siervo, V. The geosites of the Cilento-Vallo di Diano national park (Campania region, southern Italy). II Quat. 2005, 18, 101-112.

56. Aloia, A.; Guida, D.; Valente, A. Geodiversity in the Geopark of Cilento and Vallo di Diano as heritage and resource development. Rend. Online Soc. Geol. Ital. 2012, 21, 688-690.

57. Cilento, Vallo di Diano and Alburni Geopark Geosites Database. Available online: http://www.cilentoediano. it/it/geositi-gli-ambiti-paesaggio (accessed on 5 May 2020).

58. Aloia, A.; Guida, D. The Geosites: Geopark's Gaia Synphony in the Cilento, Vallo Diano and Alburni Geopark, Geopark Book n. 1; Cilento, Vallo di Diano and Alburni Geopark: Vallo della Lucania, Italy, 2014.

59. Aloia, A.; Calcaterra, D.; Guida, D.; Valloni, R. Field trip Guide book. In Proceedings of the 12th European Geopark Conference, Ogliastro Cilento, Italy, 4-7 September 2013; pp. 42-52.

60. Aloia, A.; De Vita, A.; Guida, D.; Toni, A.; Valente, A. National Park of Cilento and Vallo di Diano: Geodiversity, geotourism, geoarchaeology and historical tradition. In Proceedings of the 9th European Geopark Conference-European Geopark Network, Mytilene Lesvos, Greece, 1-5 October 2010; p. 41.

61. Aloia, A.; De Vita, A.; Guida, D.; Toni, A.; Valente, A. La geosiversità del Parco Nazionale del Cilento e Vallo di Diano: Verso il Geoparco. In Proceedings of the Atti del Convegno Nazionale "II Patrimonio Geologico: Una risorsa da proteggere e valorizzare", Sasso di Castalda, Italy, 29-30 April 2010; pp. 188-202.

62. Santangelo, N.; Amato, M.; Ascione, A.; Cafaro, S.; Calcatera, D.; Romano, P. Geological field trip n. 4: From Vallo di Diano to Angelo caves. In Field Trip Guide Book 12th European Geopark Conference; Aloia, A., Calcaterra, D., Guida, D., Valloni, R., Eds.; National Park of Cilento Vallo di Diano and Alburni: Vallo della Lucania, Italy, 2013; pp. 42-52.

63. Santangelo, N.; Bravi, S.; Santo, A. Itinerario 12 Piana del Sele, Monti Alburni e Vallo di Diano. In Guide Geologiche Regionali-Campania e Molise; Calcaterra, D., D’Argenio, B., Ferranti, L., Pappone, G., Petrosino, P., Eds.; Società Geologica Italiana: Rome, Italy, 2016; pp. 227-242, ISBN 9788894022728.

64. Chua, A.; Servillo, L.; Marcheggiani, E.; Moere, A.V. Mapping Cilento: Using geotagged social media data to characterize tourist flows in southern Italy. Tour. Manag. 2016, 57, 295-310. [CrossRef] 
65. Amodio, T. La dimensione territoriale dell'ospitalità turistica in provincia di Salerno. Boll. dell'Assoc. Ital. Cartogr. 2016, 157, 105-116. [CrossRef]

66. Italan Ministry of the Environment, Technical Analysis 2017. Available online: https://www.minambiente.it/ sites/default/files/archivio/allegati/biodiversita/Rapporto_Natura_Cultura.pdf (accessed on 31 May 2020).

67. Di Martino, P.; Petrillo, C.S. An International Project to Develop Networking for Promoting a Specific Destination: Emigration as a Tool to Enhance Tourism in Cilento Area. In Tourism Local Systems and Networking; Elsevier BV: Amsterdam, The Netherlands, 2006; pp. 219-233.

68. Brilha, J.B. Inventory and Quantitative Assessment of Geosites and Geodiversity Sites: A Review. Geoheritage 2015, 8, 119-134. [CrossRef]

69. Marciano, R.; Munno, R.; Petrosino, P.; Santangelo, N.; Santo, A.; Villa, I. Late quaternary tephra layers along the Cilento coastline (southern Italy). J. Volcanol. Geotherm. Res. 2008, 177, 227-243. [CrossRef]

70. Greco, G.; Krinzinger, F. Velia. Studi e Ricerche; Panini Franco Cosimo: Modena, Italy, 1994; ISBN 8876863087.

71. Cicala, L. Il Quartiere occidentale di Elea-Velia. Mélanges l'Éc. Fr. Rome Antiq. 2013, 125. [CrossRef]

72. Ermolli, E.R.; Romano, P.; Ruello, M.R. Human-Environment Interactions in the Southern Tyrrhenian Coastal Area: Hypotheses from Neapolis and Elea-Velia. In The Ancient Mediterranean Environment between Science and History; Brill: Leyden, The Netherlands, 2013; pp. 213-231.

73. UNESCO. UNESCO Global Geoparks. Celebrating Earth Heritage, Sustaining local Communities; UNESCO: Paris, France, 2016.

74. Moreira, J.C. Interpretative Panels About the Geological Heritage-A Case Study at the Iguassu Falls National Park (Brazil). Geoheritage 2012, 4, 127-137. [CrossRef]

75. Migoń, P.; Pijet-Migoń, E. Interpreting Geoheritage at New Zealand's Geothermal Tourist Sites-Systematic Explanation Versus Storytelling. Geoheritage 2016, 9, 83-95. [CrossRef]

76. Crawford, K.R.; Black, R. Visitor Understanding of the Geodiversity and the Geoconservation Value of the Giant's Causeway World Heritage Site, Northern Ireland. Geoheritage 2011, 4, 115-126. [CrossRef]

77. Vacchi, M.; Marriner, N.; Morhange, C.; Spada, G.; Fontana, A.; Rovere, A. Multiproxy assessment of Holocene relative sea-level changes in the western Mediterranean: Sea-level variability and improvements in the definition of the isostatic signal. Earth Sci. Rev. 2016, 155, 172-197. [CrossRef]

78. Chappell, J.; Omura, A.; Esat, S.; McCulloch, M.; Pandolfi, J.M.; Ota, Y.; Pillans, B. Reconciliaion of late Quaternary sea levels derived from coral terraces at Huon Peninsula with deep sea oxygen isotope records. Earth Planet. Sci. Lett. 1996, 141, 227-236. [CrossRef]

79. Waelbroeck, C.; Labeyrie, L.; Michel, E.; Duplessy, J.; McManus, J.; Lambeck, K.; Balbon, E.; Labracherie, M. Sea-level and deep water temperature changes derived from benthic foraminifera isotopic records. Quat. Sci. Rev. 2002, 21, 295-305. [CrossRef]

80. Visitors to Italian Museum and Archaeological Areas. Available online: http://www.statistica.beniculturali.it/ Visitatori_e_introiti_musei_16.htm (accessed on 6 May 2020).

81. Amorosi, A.; Colalongo, M.; Pasini, G.; Preti, D. Sedimentary response to Late Quaternary sea-level changes in the Romagna coastal plain (northern Italy). Sedimentology 1999, 46, 99-121. [CrossRef]

82. Kayan, I. Holocene stratigraphy and geomorphological evolution of the Aegean coastal plains of Anatolia. Quat. Sci. Rev. 1999, 18, 541-548. [CrossRef]

83. Amato, V.; Filocamo, F. Geoarchaeotourism along the coast of the Campania region (southern Italy). In Proceedings of the Geomorphic Processes and Geoarchaeology: From Landscape Archaeology to Archaeotourism, International Conference, Moscow, Russia, 20-24 August 2012; pp. 25-28.

84. Itinerary Proposed by the Cilento, Vallo di Diano and Alburni Geopark. Available online: http://www. cilentoediano.it/en/escursioni (accessed on 27 May 2020).

85. Migoń, P.; Pijet-Migoń, E. Natural Disasters, Geotourism, and Geo-interpretation. Geoheritage 2018, 11, 629-640. [CrossRef]

86. Coratza, P.; De Waele, J. Geomorphosites and Natural Hazards: Teaching the Importance of Geomorphology in Society. Geoheritage 2012, 4, 195-203. [CrossRef]

(C) 2020 by the authors. Licensee MDPI, Basel, Switzerland. This article is an open access article distributed under the terms and conditions of the Creative Commons Attribution (CC BY) license (http://creativecommons.org/licenses/by/4.0/). 